\title{
Konaklama İşletmelerinde Faaliyet Tabanlı Maliyetleme Yöntemi: Bir Otel İşletmesinde Vaka Çalışması
}

\author{
Activity Based Costing Method In The Hospitality Industry: A Case Study In A Hotel
}

\author{
Ayşegül CíĞER*
}

$\ddot{O} Z$

Bu çalışmanın amacı, Antalya ilinde faaliyet gösteren bir otel işletmesinde, faaliyet tabanlı maliyetleme (FTM) yöntemine göre maliyetlerin nasıl hesaplanacağını göstermek ve ortaya çıkan maliyet sonuçlarını tartışmaktır. Maliyet hesaplamaları otelin önbüro, kat hizmetleri, mutfak, bulaşıkhane ve servis bölümlerinde yapılmıştır. Her bölümdeki faaliyetlerin maliyeti maliyet sürücüleri kullanılarak belirlenmiştir. FTM yöntemi uygulamasının sonucunda, maliyetlerin azaltılması için hangi faaliyetlerin maliyetinin katlanılabilir olduğu hangi faaliyetlerin maliyetlerinin düşürülebileceğ ortaya çıkmıştır. Hedeflenen maliyete yaklaşılmasında maliyetlerin nerede ve hangi faaliyette kaliteyi etkilemeden azaltılması gerektiği konusunda, yöneticilere en doğru kararı aldıracak bilgilerin üretilmesini sağlamıştır. FTM yöntemine göre hesaplanan birim maliyet geleneksel maliyet yöntemine göre hesaplanan birim maliyete göre daha doğru ve gerçekçidir. Satış fiyatının piyasada belirlendiği bir ortamda kar marjının artırılabilmesi için FTM önemli bir araçtır. FTM yönteminin uygulanmasindaki en önemli zorluklar, otel işletmesinde maliyet muhasebesi sistemi ve eğitimli personel olmamasıdır.

\section{ANAHTAR KELIMELER}

Faaliyet Tabanlı Maliyetleme Yöntemi, Konaklama İşletmeleri, Otel, Maliyet Yönetimi

\begin{abstract}
The aim of this study is to show how to calculate costs according to activity based costing (ABC) method in a hotel business in Antalya and discuss the resulting cost results. Cost calculations are made in the front office, housekeeping, kitchen, dishwasher and service departments of the hotel. The cost of activities in each segment is determined using cost drivers. As a result of the application of $A B C$ method, it has emerged which cost of activities is bearable in order to reduce costs and which costs of activities can be reduced. It has produced the information that will make the most accurate decision for the managers about where the costs should be reduced without affecting the quality in approaching the target cost. The unit cost calculated according to the ABC method is more accurate and realistic than the unit cost calculated according to the traditional cost method. ABC is an important tool for increasing the profit margin in an environment where the sales price is determined in the market. The most important difficulties in the application of the ABC method are the cost accounting system and lack of trained personnel in the hotel business.
\end{abstract}

KEYWORDS

Activity Based Costing Method, Hospitality Industry, Hotel, Cost Management

\begin{tabular}{|c|c|c|}
\hline \multicolumn{2}{|c|}{ Makale Geliş Tarihi / Submission Date } & \multicolumn{1}{c|}{$\begin{array}{c}\text { Makale Kabul Tarihi / Date of Acceptance } \\
\text { 23.12.2019.02.2020 }\end{array}$} \\
\hline \multirow{3}{*}{ Atıf } & $\begin{array}{l}\text { Ciğer, A. (2020). Konaklama İşletmelerinde Faaliyet Tabanlı Maliyetleme Yöntemi: Bir Otel İşletmesinde Vaka } \\
\text { Çalışması. Selçuk Üniversitesi Sosyal Bilimler Meslek Yüksekokulu Dergisi, 23 (1), 164-185. }\end{array}$ \\
\hline
\end{tabular}

\footnotetext{
* Dr. Öğr. Üyesi, Akdeniz Üniversitesi UBF, aysegulc@ akdeniz.edu.tr, ORCID: 0000-0001-9128-4974
} 


\section{GİRIŞ}

Günümüzde turizm, dünyanın en büyük endüstrilerinden biri haline gelmiştir. Dünya Turizm Örgütü’nün hazırladığı rapora göre, dünya çapında bir ihracat kategorisi olarak turizm, kimyasallar ve yakıtlar ve otomotiv ürünlerinden sonra üçüncü sırada yer almaktadır. Gelişmekte olan birçok ülkede turizm, ihracat kategorisinde en üstte yer almaktadır (UNWTO, 2018:6). Dolayısıyla turizmin gelir getirici ve döviz girdisi sağlama özelliği, ülke ekonomileri üzerinde olumlu etkiler yaratmaktadır (Yağc1, 2003:16).

Türkiye'de de, turizm gelirlerinin ekonomiye önemli katkısı bulunmaktadır. Özellikle 2001- ve 2008 kriz dönemlerinde, turizm gelirlerinin gayri safi yurt içi hasılasındaki payı 2001 yılında $\% 4,11$ ve 2008 yılında pay1 \%3,15 olarak gerçekleşmiştir. Söz konusu oranlar, diğer dönemlerdeki oranlara göre yüksektir. 2018 yılında ise bu oran \%3,8 olarak gerçekleşerek önemli bir pay aldığı ifade edilebilir (www.tursab.org.tr/istatistiklericerik/turizm-geliri, Erişim Tarihi: 20.11. 2019).

Turizm endüstrisi içinde faaliyet gösteren ve endüstrinin bel kemiği olan konaklama işletmeleri, günümüzde en önemli iş kollarından biri haline gelmiştir. Özellikle 21. yüzyılda, insanların gelir seviyesindeki artışlar, boş zamanlarının artması, insanların rahatlığına ve dinlenmesine daha çok önem vermeleri, teknoloji ve küreselleşmeyle seyahatlerin artması, konaklama işletmelerinin gelişmesine ve ekonomide daha önemli hale gelmesine neden olmuştur. Turizm endüstrisi küreselleşme süreci içinde yaşanan tüm değişmelere açık olacak ve küreselleşmenin olumlu özelliklerini kabul ederek başarıya ulaşmak için çaba gösteren ve gelişen bir endüstri olacaktır (Holjevac, 2003:130-131). Türkiye'de 2014 yılında turizm yatırım belgeli işletme sayısı 1970 yılına göre \%271; turizm işletme belgeli tesis sayıs1 ise \%972 oranında artarak (www.turob.com/tr/istatistikler/turkiye-otel-istatistikleri-9d67c3c, Erişim Tarihi: 20.11.2019) dikkat çekici bir artış olmuştur. Konaklama işletmelerinin hızlı bir şekilde büyümesi ve işletme sayısının artması beraberinde yoğun bir rekabet ortamını doğurmaktadır. Rekabet, artık sadece ulusal pazarda değil küresel pazarda da işletmelerin varlığını tehdit edecek hatta yok edecek şiddette yaşanmaktadır. İşletmeler, böyle bir ortamda varlıklarını sürdürebilmek ve stratejik kararlar verebilmek için maliyet muhasebesi sisteminden sağlanan bilgilere daha fazla ihtiyaç duymaktadırlar. İşletmeler, uygun maliyet muhasebesi sistemi ile daha doğru maliyetler belirleyebilir, gereksiz maliyetleri azaltabilir, karlılığını geliştirebilir, müşteri tatminini artırabilir ve böylece pazarda rekabetçi avantaj sağlayabilir. Diğer taraftan otel işletmelerinin ekonomik durgunluk ve artan enflasyon dönemlerinde yapmaları gereken en önemli eylem maliyetlerini yeniden yapılandırmaktır. Bu yapılandırma sürecinde; hızlı yaşanan ekonomik ve teknolojik gelişmeler, artan şiddetli rekabet, müşteri gereksinimlerini kapsayacak bir şekilde performans ölçümlerin gerekliliği, etkin maliyet kontrolü ihtiyaçları sebepleri ile geleneksel maliyet muhasebesi sistemi yeterli olmayabilir. Bu yetersizliği ortadan kaldırmak amacı ile faaliyet tabanlı maliyetleme (FTM) yöntemi kullanılabilir.

İşletmelerin, maliyet azaltmada etkili olan, maliyetlerin daha etkin hesaplanmasını sağlayan, müşteri ihtiyaçlarını ve beklentilerini maksimum düzeyde karşılayabilmek için yeni maliyet yöntemlerini kullanmalarını gerekli hale getirmiştir. Faaliyet tabanlı maliyetleme (FTM) yöntemi, bu yöntemlerden biridir. FTM, maliyet hesaplama ve yönetim muhasebesindeki en önemli yeniliklerden biri olarak kabul edilmektedir (Gosselin, 2007:666). Ayrıca, FTM; hedef maliyete ulaşmak için kullanılan önemli araçlardan biridir (Karcioğlu, 2000: 190).

Kaplan ve Cooper (1998) ve Brignall (1997), oteller gibi sabit ve dolaylı maliyeti yüksek olan işletmelerin, FTM yöntemini kullanmaları gerektiğini savunmaktadır.

Çalışmanın amacı, bir otel işletmesinin temel hizmet bölümlerinde FTM yönteminin uygulanmasının sonuçlarını değerlendirmek ve yarattığı etkiyi tartışmaktır. Çalışmanın sonuçları, diğer vaka çalışmalarının sonuçlarıyla uyumludur.

Çalışma iki bölümden oluşmaktadır. Birinci bölümde FTM'nin tanımı, amacı ve otel işletmelerinde FTM'nin gerekliliği ve alanda yapılan çalışmalar; ikinci bölümde ise 5 yıldızlı bir otel işletmesinde yapılan vaka çalışması yer almaktadır.

Çalışmada faaliyetler ve maliyet hesaplamaları diğer yapılan vaka çalışmalarına göre daha ayrıntılı olması açısından farklılık göstermektedir. Çalışma muhasebe sistemi olan otel işletmeleri için uygulanabilir olma özelliği taşımaktadır.

\section{OTEL İŞLETMELERINDE FAALIYET TABANLI MALIYETLEME YÖNTEMİ}

\subsection{Faaliyet Tabanlı Maliyetleme Yönteminin Tanımı ve Amacı}

Geleneksel maliyet sistemi, aynı zamanda hacim tabanlı maliyet sistemi olarak da adlandırılmaktadır. Nitekim genel üretim giderlerinin dağıtımında hacim esasına dayanan maliyet sistemi kullanıldığında, ürün hacminde değişiklik meydana geldiğinde ürün maliyetleri de değişmektedir. Geleneksel maliyet sistemleri, 
genel üretim giderlerini, ürünün maliyet oluşturduğu esasına dayalı olarak ürün tabanlı olarak izlemektedir (Turney, 1990: 40-42).

FTM, üretimde gerçekleştirilen faaliyetler üzerine odaklanmaktadır. FTM, maliyet nesneleri, kaynaklar ve faaliyetlerin performansı ve maliyetini ölçen, kaynakları faaliyetlere ve faaliyetleri maliyet nesnelerine yükleyen, faaliyetlere neden olan maliyet sürücülerinin ilişkilerini tanımlayan bir yöntemdir (Plowman, 2001: 13).

Bir diğer tanıma göre FTM, ürün, müşteri, hizmet gibi maliyet nesnelerini ölçen bir yöntemdir. FTM, öncelikle işletme tarafindan gerçekleştirilen faaliyetlere kaynak maliyetlerini yükler. Daha sonra, faaliyet maliyetleri, ürünlere, müşterilere ve hizmetlere o fayda yüklenir veya faaliyetler için talebi yaratır (Kidwell, ve diğ., 2002: 63). Diğer bir ifadeyle, faaliyetler işletme kaynaklarını tüketir, böylece maliyetlerin oluşmasında ürünler sıra ile faaliyetleri tüketir.

FTM, esas olarak ürün maliyeti için kullanılmaktadır. FTM, geliştirilmiş ürün maliyet bilgisi sağlama yanında aynı zamanda maliyet azaltma olanaklarını yaratan güçlü bir yöntemdir. Zaten, günümüz muhasebe sistemleri, maliyet azaltma olanaklarını ve maliyet bilgisini sağlamak durumundadır (Sievanen ve Tornberg, 2002: CSC.15.1).

FTM yöntemi, özellikle işletmelerde çok sayıda ürün üretildiği ya da üretim süreçleri karmaşık hale geldiği zaman ve maliyet yapısının değişmesinden dolayı, ürün maliyetinin hesaplanmasında geleneksel maliyet yöntemlerine göre daha doğru bilgi sağlayabilmesi amaciyla geliştirilmiştir (Latshaw ve Cortese, 2002: 3031). FTM, ürün maliyetlerini oluşturan endirekt giderleri yani genel üretim giderlerinin ürünlere yüklenmesi ile ilgili bir yöntemdir. Dolayısıyla FTM, üretim hacmini esas alan geleneksel maliyet yöntemine alternatif bir yöntem olarak ortaya çıkarılmıştır. FTM'nin benimsenmesinin en önemli algılanan yararlarından biri, ürün maliyetlemesi için daha doğru maliyet bilgisidir (Cooper ve Kaplan, 1991: 130; Cohen ve diğ., 2005:983).

FTM modeli, başlangıçta ürün maliyetlerinin daha doğru hesaplanması amacı ile kullanılırken; müşteri karlılı̆̆ı, işgücünden faydalanma, dağıtım kanalları, finansal olmayan maliyetler ve diğer yönetim sorunları gibi faktörleri de içine alarak Faaliyet Tabanlı Maliyet Yönetimi(FTMY)'ni de kapsamıştır (Plowman, 2001: 9; Babad ve Balachandran 1993: 563; Chenhall ve Smith 1999: 38). FTMY(FTY ve FTM bazen eşanlaml1 olarak kullanılmaktadır (Cagwin ve Bouwman, 2002: 1), FTM altında geliştirilen bilgileri kullanır ve performans ölçümü, faaliyet analizi ve maliyet sürücüsü analizlerini kapsamaktadır. FTYM, yönetime maliyet tabanlı faaliyet kararlarının desteklenmesinde, organizasyon gelişiminde ve maliyetlerin yönetiminde yardımcı olur(Agrawal, ve diğ., 1998: 64). Bu kapsamda FTM modeli Şekil 1'de (CIMA Global, 2001:4) gösterilmiştir.

\section{Şekil 1: Faaliyet Tabanlı Maliyet Modeli}

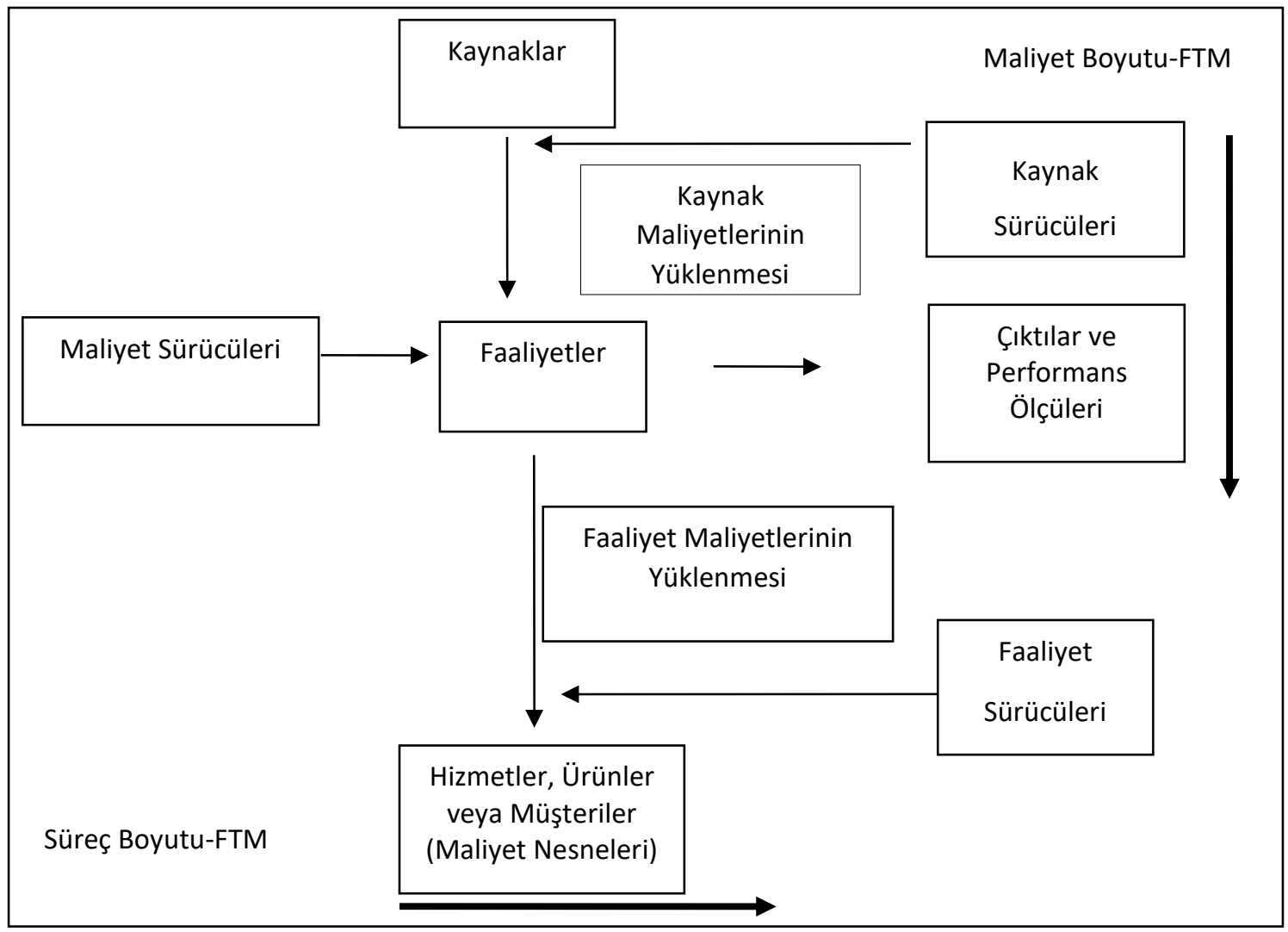

Selçuk Üniversitesi Sosyal Bilimler Meslek Yüksekokulu Dergisi, Yıl: 2020 Cilt: 23 Sayı:1 
FTM modeli, şekilden de görüldüğü gibi süreç ve maliyet boyutu olmak üzere iki tür bilgiyi içermektedir. Maliyet boyutunda dikey olarak; faaliyetler kaynakları tüketir diğer taraftan ürün ve müşteri gibi maliyet nesneleri ise faaliyetleri tüketir. Dolayısıyla dikey eksen maliyet tüketim zinciri olarak adlandırılabilir. Kısaca maliyet boyutu maliyetlerin genel akışını gösterir. Yatay eksende yer alan süreç boyutu ise işleri ve performansla ilgili bilginin akışını gösterir (Raffish, 1991: 38).

Kaynaklar faaliyetlere atanır, ardından faaliyetler kullanımlarına bağlı olarak maliyet nesnelerine atanır. FTM, maliyet sürücülerinin faaliyetlerle nedensel ilişkisini tanır (Raffish ve Turney, 1991: 58).

FTM sürecinde beş amaç ön plana çıkmaktadır (Cokins, 1996: 9);

- Düşük katma değere sahip, diğer bir ifadeyle de mamul ve hizmet üretiminde değer yaratmayan faaliyetlere ait maliyetleri ortadan kaldırmak ya da minimize etmek,

- Karlılığı artırmak üzere gerçekleştirilen katma değeri yüksek faaliyetlerin kolaylaştırılmasında, etkin ve verimli bir bilgi tabanı sağlamak,

- Problemlerin temel nedenlerinin belirlenmesini ve düzeltilmesini sağlamak,

- Zayıf varsayımlar ve yetersiz maliyet dağıtımından kaynaklanan yanlışlıkları ortadan kaldırmak,

- Yöneticilerin doğru karar almalarında doğru maliyet bilgileri sağlayabilmek.

Yönetim muhasebesi alanında yapılan bazı ampirik çalışmalar FTM'nin faydalarını organizasyonel ve finansal açıdan araştırmıştır. Bulgular, işletmeler geleneksel maliyetlendirme sistemleri yerine FTM kullandıklarında, firmanın finansal performansının arttığını göstermektedir (Diavastis, ve diğ., 2016: 762).

\subsection{Otel İşletmelerinde Faaliyet Tabanı Maliyet Yöntemini Kullanmanın Gerekliliği ve Sağlayacağı Yararlar}

Otel endüstrisi söz konusu olduğunda, otel işletmelerinde, direkt ilk madde malzeme, direkt işçilik ve genel üretim gideri ayrımı yapılmamaktadır. Giderler direkt (doğrudan) giderler ve endirekt (dolaylı) giderler olarak takip edilebilmektedir. Oteller dolaylı olarak yüksek maliyetlere ve sabit bir maliyet bileşenine sahiptir (Brignall, 1997: 329; Pavlatos ve Paggios, 2007: 39) Dolaylı giderlerin fazla olmas1, giderlerin ürün ve hizmetlere yüklenmesini daha hassas hale getirmiştir. Ayrıca sabit maliyetlerin değişken maliyetlere oranla oldukça yüksek olması, maliyetlerin doğru hesaplanmasında yetersiz olmasına neden olmaktadır.

Geleneksel maliyetlendirme bu maliyetlerin doğru bir şekilde dağıtılmasında yetersiz ve başarısız olur. Çünkü maliyetlerin büyük kısmı dolaylıdır. Bu nedenle otellerde FTM yönteminin kullanılması, daha doğru maliyet elde etme açısından faydalı olacaktır.

Otellerin FTM'yi benimsemelerindeki nedenler, dolaylı maliyetlerin doğru dağıtımı yoluyla etkin ürün stratejilerinin uygulanması, ayrıntılı maliyet bilgilerinin kullanılması yoluyla rekabetçi bir pazarda konumlandırılması, katma değer yaratan faaliyetler ve örgütsel amaçlara maliyet kontrolü yoluyla ulaşılmasıdır (Patiar 2016: 3). Bununla birlikte, otellerin FTM gibi daha işlevsel maliyetlendirme sistemlerini benimsemeleri durumunda, düşük kaliteli hizmet sunmadan maliyetleri azaltabilecek, doğru fiyatlandırma kararları alabilecek, etkin performans ölçümü yapabilecek ve diğer yönetim uygulamaları için maliyet verilerinden geniş ölçüde yararlanabilecektir (Pavlatos ve Paggios, 2009: 523). FTM yöntemi, öncelikle ürün maliyetlerinin doğru bir şekilde belirlenmesi amacı ile geliştirilen bir yöntem olmasına rağmen, aynı zamanda bir performans ölçüm sistemi ve stratejik kararların alınmasında yönetime destek veren bir yöntem olarak da benimsenmiştir (Cagwin ve Bouwman 2002: 3).

Sonuç olarak, FTM'nin kullanılması, otelleri rakipler karşısında maliyet avantajı kazanmaya zorlamakta ve stratejik ve operasyonel kararlarda verimliliği arttırmakta, bu da karlılı̆̆ 1 ve finansal performansı arttırmaktadır (Patiar, 2016: 7). Bu nedenle, FTM kullanımının otel finansal performansi üzerindeki etkisi olumlu olacaktır.

Noone ve Griffin (1997) ve Mashayekhi ve Ara (2017), otellerde bir FTM sistemi tasarlamak için dört adım olduğunu belirtmektedir olduğunu belirtmektedir. $\mathrm{Bu}$ adımlardan birincisi faaliyetleri tanımlamak, ikincisi maliyet havuzlarına maliyetleri dağıtmak, üçüncüsü faaliyetlerin maliyet nesnelerine maliyetini değerlendirmek için uygun maliyet sürücülerini seçmek ve dördüncüsü de faaliyetlerin maliyetini hizmetlere ve müşterilere yüklemektir.

\subsection{Otel İşletmelerinde Faaliyet Tabanlı Maliyet Yöntemi ile İlgili Yapılan Çalışmalar}

Otellerde FTM le ilgili olarak yapılan çalışmaların çoğunlukla FTM'nin geleneksel maliyetleme yaklaşımlarından daha üstün olduğunu gösteren çeşitli çalışmalar ve yöntemin benimsenme ve uygulama düzeyini belirlemeye yönelik anket uygulamaları çalışmalarını kapsadığı görülmektedir. Konuyla ilgili ulaş1lan çalışmalar tablo 1'de verilmiştir. 
Tablo 1: FTM ile İlgili Otel İşletmelerine Yapılan Çalışmalar

\begin{tabular}{|c|c|c|c|}
\hline Yazar/Yıl & Amaç & $\begin{array}{c}\text { Yöntem } \\
\text { Örnek }\end{array}$ & Sonuç \\
\hline $\begin{array}{l}\text { Pavlatos ve Paggios, } \\
\text { (2007) }\end{array}$ & $\begin{array}{l}\text { Yunan otel endüstrisi } \\
\text { uygulamalarının maliyet } \\
\text { muhasebesi alanındaki } \\
\text { görüşlerini ortaya koymaktır. }\end{array}$ & $\begin{array}{l}\text { Anket } \\
\text { Yunanistan farklı } \\
\text { bölgeler } \\
85 \text { otel ( } 3,4 \text { ve } 5 \\
\text { y1ldılı oteller) } \\
\text { Finans yöneticileri }\end{array}$ & $\begin{array}{l}\text { Ankete katılan işletmelerin \%23,5'i FTM } \\
\text { kullanmaktadır. Ancak, az sayıda faaliyetin } \\
\text { maliyetini hesapladıklarından ayrıntılı değildir. } \\
\text { FTM kullanan oteller kullanmayanlara göre } \\
\text { daha yüksek dolaylı maliyet ve satış gelirine } \\
\text { sahiptir. }\end{array}$ \\
\hline $\begin{array}{l}\text { Pavlatos ve Paggios, } \\
\text { (2009) }\end{array}$ & $\begin{array}{l}\text { FTM kullanımına ilişkin } \\
\text { mevcut genel eğilimlere ait } \\
\text { ampirik kanıtlar sunmaktır. }\end{array}$ & $\begin{array}{l}\text { Anket } \\
\text { Yunanistan farklı } \\
\text { bölgeler } \\
85 \text { otel ( } 3,4 \text { ve } 5 \\
\text { y1ldılı oteller) } \\
\text { Finans yöneticileri }\end{array}$ & $\begin{array}{l}\text { Otellerin fiyatlandırma kararlarında ve müşteri } \\
\text { karlılık analizinde FTM'yi benimsedikleri } \\
\text { ortaya çıkmıştır. Reddetmenin temel nedenleri; } \\
\text { mevcut maliyet muhasebesi sisteminden } \\
\text { memnun olmaları ve FTM uygulamasının } \\
\text { yüksek maliyetli olmasıdır. }\end{array}$ \\
\hline $\begin{array}{l}\text { Olotu ve Adamu, } \\
\text { (2009) }\end{array}$ & $\begin{array}{l}\text { Otel endüstrisinde FTM'nin } \\
\text { uygulanabilirliğini } \\
\text { incelemektir. }\end{array}$ & $\begin{array}{l}\text { Anket ve yarı } \\
\text { yapılandırılmış } \\
\text { görüşme, } \\
\text { Nijerya Keffi } \\
\text { bölgesi } \\
5 \text { otel, } 10 \text { görüşme } \\
\text { Yönetici ve } \\
\text { muhasebeciler }\end{array}$ & $\begin{array}{l}\text { Ankete katılan hiçbir otelin FTM kullanmadığı } \\
\text { ortaya çıkmıştır. }\end{array}$ \\
\hline $\begin{array}{l}\text { Zounta ve Bekiaris } \\
(2009)\end{array}$ & $\begin{array}{l}\text { Otel muhasebecilerinin ve } \\
\text { yöneticilerinin maliyete dayalı } \\
\text { yönetim ve karar vermenin } \\
\text { nasıl olduğu konusundaki } \\
\text { algılarını incelemektedir. }\end{array}$ & $\begin{array}{l}\text { Anket } \\
\text { Yunanistan farklı } \\
\text { bölgeler } \\
72 \text { lüks otel ( } 5 \\
\text { y1ldılı oteller) } \\
\text { Otel yöneticileri }\end{array}$ & $\begin{array}{l}\text { Otel işletmelerinin \%71'i FTM'nin farkında } \\
\text { ancak sadece \%15'nin yöntemi kullandığı } \\
\text { ortaya çıkmıştır. }\end{array}$ \\
\hline Dalci, ve diğ., (2010) & $\begin{array}{l}\text { Bir Türk otel işletmesinde } \\
\text { zamana dayalı faaliyet tabanlı } \\
\text { maliyetleme (ZDFTM) } \\
\text { kullanarak müşteri karlılık } \\
\text { analizinin uygulanmasını } \\
\text { göstermektir. }\end{array}$ & $\begin{array}{l}\text { Vaka çalışması } \\
\text { Türkiye Mersin } \\
4 \text { yıldızlı otel }\end{array}$ & $\begin{array}{l}\text { Geleneksel FTM yönteminde kârsız bulunan } \\
\text { bazı müşteri segmentlerinin ZDFTM } \\
\text { kullanılarak karlı olduğu ortaya çıkmıştır. }\end{array}$ \\
\hline El-Deeb ve diğ., (2011) & $\begin{array}{l}\text { Satın alma faaliyetlerinin } \\
\text { performansını optimize etmek } \\
\text { için satın alma bölümünde } \\
\text { uygulanabilecek FTM } \\
\text { yaklaşımının uygulanması } \\
\text { yoluyla yeni bir model } \\
\text { kullanmayı önermektedir }\end{array}$ & $\begin{array}{l}\text { Anket } \\
\text { Misır Kahire } \\
30 \text { otel } 213 \text { anket (5 } \\
\text { yıldızlı oteller) } \\
\text { Yönetici ve } \\
\text { çalışanlar }\end{array}$ & $\begin{array}{l}\text { FTM modelinin, konaklama endüstrisinde satın } \\
\text { alma performansını artırdığı tespit edilmiştir. }\end{array}$ \\
\hline $\begin{array}{l}\text { Vazakidis ve } \\
\text { Karagiannis, (2011) }\end{array}$ & $\begin{array}{l}\text { Geleneksel maliyetlendirme ve } \\
\text { FTM modellerinin üst düzey } \\
\text { bir otel işletmesinde } \\
\text { uygulanmasının sonucunu } \\
\text { tartışmaktır. }\end{array}$ & $\begin{array}{l}\text { Vaka Çalışması } \\
\text { Yunanistan } \\
5 \text { yıldızlı otel }\end{array}$ & $\begin{array}{l}\text { Oda başına günlük farklı maliyetler ortaya } \\
\text { çıktığı gibi, aynı zamanda birçok yönetim } \\
\text { kararına yararlı olacak bilgiler üretmiştir. } \\
\text { Stratejik karar vermede maliyet bilgisi daha } \\
\text { doğru hesaplandı. Giderler ve fiyat politikasının } \\
\text { nasıl olması gerektiğine karar vermede yardımcı } \\
\text { olur. }\end{array}$ \\
\hline Pavlatos, (2011) & $\begin{array}{l}\text { Farklı işletme özelliklerinin } \\
\text { (örneğin boyut, maliyet, yapı, } \\
\text { rekabet) karmaşık maliyetlerin } \\
\text { benimsenmesini } \\
\text { etkileyebileceği, örneğin FTM } \\
\text { gibi sistemleri inceleme ve } \\
\text { tanımlamasıdır, } \\
\text { Otelcilik bağlamında ve benzer } \\
\text { çalışmalarla diğer } \\
\text { endüstrilerdeki farklılıkları } \\
\text { tespit etmek. }\end{array}$ & $\begin{array}{l}\text { Anket } \\
\text { Yunanistan farklı } \\
\text { bölgeler } \\
85 \text { otel } \\
\text { Finans yöneticileri }\end{array}$ & $\begin{array}{l}\text { Bir otelin maliyet yapısındaki dolaylı } \\
\text { maliyetlerin oranı ve ABC sistemlerinin } \\
\text { benimsenmesi ile pozitif bir ilişki vardır. } \\
\text { Stratejik yönetim muhasebesi tekniklerinin } \\
\text { kullanımı ile ABC sistemlerinin benimsenmesi } \\
\text { arasında pozitif bir ilişki vardır. }\end{array}$ \\
\hline
\end{tabular}




\begin{tabular}{|c|c|c|c|}
\hline $\begin{array}{l}\text { Bekçioğlu ve Köroğlu, } \\
\text { (2012) }\end{array}$ & $\begin{array}{l}\text { Bir otel işletmesinin katlandığı } \\
\text { maliyetlerin ZDFTM } \\
\text { yöntemiyle hesaplanmasının, } \\
\text { faaliyet tabanlı maliyetleme } \\
\text { yöntemine göre, doğuracağı } \\
\text { farklılıkları analiz ederek } \\
\text { belirlemektir }\end{array}$ & $\begin{array}{l}\text { Vaka Çalışması } \\
\text { Türkiye Muğla } \\
\text { Marmaris } \\
4 \text { yıldızlı otel }\end{array}$ & $\begin{array}{l}\text { ZDFTM yönteminin, geleneksel faaliyet tabanlı } \\
\text { maliyetleme yöntemine göre, daha doğru } \\
\text { maliyet bilgisi sağladığı belirlenmiştir. }\end{array}$ \\
\hline Vij, (2012) & $\begin{array}{l}\text { Hindistan otel endüstrisi } \\
\text { tarafından benimsenen maliyet } \\
\text { yapıları ve yönetimi } \\
\text { konusundaki mevcut } \\
\text { uygulamaları ortaya } \\
\text { koymaktır. }\end{array}$ & $\begin{array}{l}\text { Anket } \\
\text { Hindistan farklı } \\
\text { bölgeler } \\
20 \text { otel ( } 3.4 \text { ve } 5 \\
\text { y1ldılı oteller) } \\
\text { Yönetciler } \\
\end{array}$ & $\begin{array}{l}\text { Otel işletmelerinin FTM uygulayarak maliyet } \\
\text { muhasebesi sistemlerini modernize etmeleri } \\
\text { gerektiği ortaya çıkmıştır. }\end{array}$ \\
\hline $\begin{array}{l}\text { Basuki ve Dwiputri, } \\
\text { (2014) }\end{array}$ & $\begin{array}{l}\text { Otelin odalar bölümüne } \\
\text { ZDFTM yöntemini uygulamak } \\
\text { ve mevcut maliyet sistemi ile } \\
\text { karşılaştırmak. }\end{array}$ & $\begin{array}{l}\text { Vaka Çalışması } \\
\text { Endonezya Malang } \\
5 \text { yıldızlı Otel }\end{array}$ & $\begin{array}{l}\text { ZDFTM yönteminin, karar verme için } \\
\text { geleneksel maliyetlendirme yaklaşımından daha } \\
\text { doğru maliyet bilgisi ürettiği ve fiyatlandırmada } \\
\text { esneklik yarattığı ortaya çıkmıştır. }\end{array}$ \\
\hline Alsoboa ve diğ., (2015) & $\begin{array}{l}\text { Stratejik karar verme } \\
\text { tekniklerinin kullanılmasının } \\
\text { Ürdün otellerinin performansı } \\
\text { üzerindeki etkilerini } \\
\text { incelemektedir. }\end{array}$ & $\begin{array}{l}\text { Anket } \\
\text { Ürdün } \\
42 \text { otel } \\
\text { (4 ve } 5 \text { yıldızlı } \\
\text { oteller) } \\
\text { Yönetici ve finans } \\
\text { yöneticileri }\end{array}$ & $\begin{array}{l}\text { ABC sisteminin stratejik karar verme } \\
\text { tekniklerinin Ürdün otelleri tarafından } \\
\text { kullanıldığı ortaya çıkmıştır. FTM yönteminin } \\
\text { ve stratejik karar verme tekniklerinin Ürdün } \\
\text { otellerinin performansı üzerinde istatistiksel } \\
\text { olarak anlamlı bir etkisi olduğunu göstermiştir. }\end{array}$ \\
\hline $\begin{array}{l}\text { Fathi ve Dozdahiri, } \\
(2015)\end{array}$ & $\begin{array}{l}\text { FTM uygulamasını } \\
\text { etkileyebilecek dört olası } \\
\text { örgütsel, çevresel, bireysel ve } \\
\text { teknolojik faktörleri } \\
\text { belirlemektedir. }\end{array}$ & $\begin{array}{l}\text { Anket } \\
\text { İran Tahran } \\
5 \text { yıldızlı otel, } 205 \\
\text { anket } \\
\text { Yönetici ve } \\
\text { çalışanlar }\end{array}$ & $\begin{array}{l}\text { Organizasyonel, teknolojik, bireysel ve çevresel } \\
\text { faktörlerin otel endüstrisinde FTM } \\
\text { uygulamasını etkilediği sonucu ortaya çıkmıştır. } \\
\text { Bireysel faktörün ise en önemlisi olduğu } \\
\text { belirlenmiştir. Deneyimli çalışanların FTM } \\
\text { uygulamasının başarısı için daha etkili oldukları } \\
\text { belirlenmiştir. }\end{array}$ \\
\hline $\begin{array}{l}\text { Diavastis, ve diğ., } \\
\text { (2016) }\end{array}$ & $\begin{array}{l}\text { Muhasebe Bilgi Sistemleri } \\
\text { (MBS) kullanıcı memnuniyeti } \\
\text { ve FTM kullanımının otel } \\
\text { finansal performansı } \\
\text { üzerindeki etkileşim etkisini } \\
\text { incelemeyi amaçlamaktadır }\end{array}$ & $\begin{array}{l}\text { Anket } \\
\text { Yunanistan } \\
\text { farklı bölgelerde } \\
103 \text { otel (Orta ve } \\
\text { büyük ölçekli } \\
\text { oteller) } \\
\text { Finans ve muhasebe } \\
\text { yöneticileri }\end{array}$ & $\begin{array}{l}\text { FTM kullanımı MBS kullanıcı memnuniyeti ile } \\
\text { etkileşime girdiğinde, otel finansal } \\
\text { performansının iyileştirildiği ortaya çıkmıştır. }\end{array}$ \\
\hline Özer ve Bilici (2017) & $\begin{array}{l}\text { Van ilinde faaliyet gösteren } \\
\text { konaklama işletmelerinin FTM } \\
\text { yönteminin uygulanabilirliğini } \\
\text { araştırmayı amaçlamaktadır. }\end{array}$ & $\begin{array}{l}\text { Anket } \\
\text { Türkiye Van ili } \\
38 \text { otel (Turizm } \\
\text { İşletme Belgeli ve } \\
\text { Belediye Belgeli) } \\
\text { Muhasebe } \\
\text { yöneticileri }\end{array}$ & $\begin{array}{l}\text { FTM uygulayan işletmelerin daha doğru maliyet } \\
\text { hesapladıkları, ancak FTM uygularken } \\
\text { faaliyetlerin belirlenmesinin zor olduğu ortaya } \\
\text { çıkmıştır. }\end{array}$ \\
\hline $\begin{array}{l}\text { Mashayekhi ve Ara } \\
\text { (2017) }\end{array}$ & $\begin{array}{l}\text { İran'daki otelcilik sektöründe } \\
\text { FTM uygulamasına ait bazı } \\
\text { deneysel kanıtlar sağlamak ve } \\
\text { geleneksel malyetlendirme } \\
\text { yöntemi ile karşılaştırmak. }\end{array}$ & $\begin{array}{l}\text { Vaka Çalışması } \\
\text { İran Tebriz } \\
4 \text { yıldızlı Otel }\end{array}$ & $\begin{array}{l}\text { İki yöntemde birim başına farklı maliyetler elde } \\
\text { edildi. FTM daha doğru ve ayrıntılı bilgiler } \\
\text { sağlamaktadır. }\end{array}$ \\
\hline $\begin{array}{l}\text { Ardiansyah ve } \\
\text { diğ.,(2017) }\end{array}$ & $\begin{array}{l}\text { Otelin mevcut sistemi ve } \\
\text { ZDFTM sistemini kullanarak } \\
\text { müşteri karlılı̆̆ } 1 \text { analizinin } \\
\text { (MKA) karşılaştırılmasını } \\
\text { yapmak. }\end{array}$ & $\begin{array}{l}\text { Vaka Çalışması } \\
\text { Endonezya } \\
\text { Jogjakarta } \\
5 \text { yıldızlı Otel }\end{array}$ & $\begin{array}{l}\text { Geleneksel maliyet sistemi, yanlış müşteri } \\
\text { maliyeti ve karlılık seviyelerine neden olan bir } \\
\text { maliyet sistemi olarak kullanılmaktadır. } \\
\text { ZDFTM, daha yüksek karlılık ve kullanılmayan } \\
\text { kapasitenin her ana faaliyette } \\
\text { bilgilendirilmesinin sonucu olması nedeniyle } \\
\text { daha doğru olduğu kanıtlanmıştır. Müşteriler } \\
\text { tarafından tüketilen toplam maliyetler hakkında } \\
\text { daha doğru bilgi sunduğu gibi, } \\
\text { MKA'dan alınan bilgiler yöneticiler için } \\
\text { fiyatlandırma politikasının belirlenmesinde ve } \\
\text { stratejik kararların alınmasında dikkate } \\
\text { alıabileceği tespit edilmiştir. }\end{array}$ \\
\hline
\end{tabular}




\begin{tabular}{|l|l|l|l|}
\hline Faria, ve diğ., (2018) & Otellerde müş̧eri karlılık & Anket & Otellerin FTM yöntemini benimsemediği, \\
& analizinin yapılmasında & Portekiz Algarve & geleneksel maliyet yöntemlerini kullanmayı \\
& Faaliyete dayalı maliyet & bölgesi & tercih ettiği sonucu ortaya çıkmıştır. Maliyetler, \\
& yönteminin benimsenme & 66 Otel (4 ve 5 & kar merkezlerinde ve maliyet merkezlerinde \\
& derecesini incelemek. & yıldılı oteller) & toplanmaktadır. \\
& Yöneticiler & \\
\hline
\end{tabular}

Tablo incelendiğinde yöntem olarak seçilen vaka çalışmaları genellikle geleneksel maliyet yöntemi ile FTM yönteminin karşılaştırılmasıdır. Çalışmaların hepsi büyük ölçekli otel işletmelerinde uygulanmıştır. Çalışmaların sonuçlarında FTM'nin geleneksel maliyet yöntemine göre daha doğru maliyet ve ayrıntılı bilgiler verdiği, fiyatlandırmada esneklik yarattığ 1 , finansal performans üzerinde olumlu etkisinin olduğu, FTM'nin müşteri karlılık analizinde (MKA) daha doğru bilgiler ürettiği ve buna göre yöneticilerin fiyatlandırma ve stratejik kararların alınmasında MKA'yı kullandığı ortaya çıkmıştır. Anket yöntemini tercih edildiği çalışmalarda, FTM yönteminin otellerde hiç ya da çok az kullanıldığı ortaya çıkmıştır. Ancak benimseme düzeyleri yüksek çıkmıştır. FTM yöntemi uygulamanın engelleyicileri ise otel işletmelerinde faaliyetleri belirlemenin zorluğu ve mevcut maliyet sisteminden memnuniyet olarak tespit edilmiştir.

\section{VAKA ÇALIŞMASI}

\subsection{Uygulamanın Amacı ve Sınırlılıkları}

Çalışmanın amacı, Antalya'daki beş yıldızlı bir otel işletmesinde üretilen hizmet maliyetini FTM yöntemi uygulayarak hesaplamak ve geleneksel maliyet yöntemine göre hesaplanan maliyet ile karşılaştırmaktır.

Çalışmadaki sınırlılıklar ise şöyledir:

İşletmede maliyet muhasebesi sistemi kurulu olmadığı için, sayısal bilgilerin bazıları tahmini olarak çalışmada yer almıştır.

Faaliyet tabanlı maliyet yöntemi uygulanırken, hizmet maliyetinin ana yapısını oluşturan, önbüro, kat hizmetleri, servis, mutfak ve bulaşıkhane hizmetleri incelenmiştir.

Çalışmada amaç hizmet maliyetini hesaplamak olduğu için, yönetimle ilgili giderler uygulamanın tamamlanabilmesi için, faaliyetlerin detaylarına girilmeden geceleme sayısı dikkate alınarak yükleme yapilacaktır.

Aylık müşteri sayısı ortalama olarak kabul edilmiştir.

\section{2. Örnek İşletme ile İlgili Bilgiler}

Örnek işletmenin sunduğu hizmet türü yarım pansiyondur ve bu sezon pazar durumundan dolayı her şey dahil sistemi uygulamak istemektedir. Ürüne dahil olan hizmetler, yiyecek, içecek, yatak, hamam-sauna, spor ve eğlence faaliyetleridir.

İşleme Antalya'ya 20 km uzaklıkta, 350 odalı, 700 yatak kapasiteli olup, yılın 12 ayı açıktır. Ancak şehir oteli olmadığından dolayı, gelen müşteriler tatil amaçlı konaklamaktadırlar. Bu nedenle işletme genelde Nisan ayından itibaren doluluk yaşamaktadır ve en yoğun doluluğun yaşandığ 1 dönem ise Haziran, Temmuz ve Ağustos aylarıdır. Antalya bölgesi özelliklerinin de etkisiyle, ilgili dönemlerde işletme, en yüksek kar marjı ile çalışmaktadır ve konaklayan müşteriler grup olarak acenta aracılığı ile gelmektedir. Dolayısıyla satış fiyatının belirlenmesinde yoğun rekabet ortamında seyahat acentaları önemli bir rol oynayabilmektedir.

İşletme Temmuz ayında \%70 oranındadır. Müşterilerin ortalama kalış süresi 7 gündür. Ayrıca işletmeye gelen müşterilerin $\% 15$ 'i çocuk ve $\% 10$ ek yatak kullanılmıştır.

Oda doluluk oranı: 350x0.70=245 odadır.

Yatak doluluk oranı: $700 \times 0.70=490$ kişi (yetişkin)

Çocuk sayısı: $245 \mathrm{x} 0.15=37$ kişi

Ek yatakla kalabilecek müşteri sayısı: $245 \mathrm{x} 0.10=25$ kişi

Toplam haftalık müşteri sayısı: 552 kişidir.

Aylık müşteri sayısı: 552x4=2.208 kişidir.

Aylık geceleme sayısı ise; 16.560 'dır

Örnek işletmede 2019 yılı Temmuz ayında gerçekleşen giderler Tablo 2'de verilmiştir.

Tablo 2: Temmuz Ayında Gerçekleşen Giderler

\begin{tabular}{|l|r|}
\hline Giderler & Tutar (TL) \\
\hline Personel Yiyecek-İçecek & $47.430,30$ \\
\hline Taşıma Giderleri & $32.173,03$ \\
\hline
\end{tabular}




\begin{tabular}{|l|r|}
\hline Elektrik & $33.225,68$ \\
\hline Su (Şebeke) & $7.824,50$ \\
\hline Peyjaz ve Havuz, Çamaşırhane (Artezyen) & $11.591,67$ \\
\hline Telefon & $9.159,09$ \\
\hline Amortisman & $281.411,52$ \\
\hline Yiyecek & $475.312,50$ \\
\hline İcecek & $288.668,98$ \\
\hline Temizlik Malzemeleri & $26.594,26$ \\
\hline Kırtasiye ve Basılı Formlar & $6.756,06$ \\
\hline Kimyasal Malzemeler & $12.803,03$ \\
\hline Buklet Malzemeler & $4.530,30$ \\
\hline LPG & $48.000,00$ \\
\hline Taşıt Akaryakıt & $16.001,82$ \\
\hline Servis Malzemeleri & $1.516,67$ \\
\hline Bakım-Onarım & $7.090,91$ \\
\hline Yedek Parça & $4.924,24$ \\
\hline Elektrik Malzemeleri & $9.651,52$ \\
\hline Sihhi Tesisat Malzemeleri & $3.348,48$ \\
\hline Misafir Ağırlama & $10.636,36$ \\
\hline TOPLAM & $\mathbf{1 . 3 3 8 . 6 5 0 , 9 2}$ \\
\hline
\end{tabular}

İşletmenin bölümlere göre aylık ücret bilgileri şöyledir:

Tablo 3 Bölümlere Göre Temmuz Ayında Gerçekleșen Personel Giderleri

\begin{tabular}{|l|c|r|}
\hline Bölümler & Personel Sayısı & Personel Ücretleri (TL) \\
\hline Ön Büro & 13 & $67.553,44$ \\
\hline Kat Hizmetleri & 40 & $120.240,00$ \\
\hline Mutfak & 25 & $134.803,95$ \\
\hline Bulaşıkhane & 8 & $29.733,77$ \\
\hline Servis & 50 & $178.262,79$ \\
\hline Çamaşırhane & 8 & $27.589,95$ \\
\hline Animasyon & 8 & $58.721,86$ \\
\hline Teknik Servis & 16 & $83.608,74$ \\
\hline Güvenlik & 10 & $64.500,84$ \\
\hline Park\&Bahçe & 10 & $37.609,95$ \\
\hline Hamam-Sauna & 1 & $4.031,30$ \\
\hline Ana Depo & 3 & $13.026,00$ \\
\hline Satış-Pazarlama & 3 & $27.007,40$ \\
\hline Yönetim & 5 & $48.119,30$ \\
\hline Muhasebe & 7 & $38.332,33$ \\
\hline İnsan Kaynakları & 3 & $21.414,84$ \\
\hline Satın Alma & 2 & $11.790,98$ \\
\hline TOPLAM & $\mathbf{2 1 2}$ & $\mathbf{9 6 6 . 3 4 7 , 4 4}$ \\
\hline
\end{tabular}




\section{3. Örnek İşletmede Faaliyet Tabanlı Maliyetleme Yönteminin Uygulanması}

\subsubsection{Faaliyetlerin Belirlenmesi}

İşletmede yapılan görüşmeler sonucunda, çok sayıda faaliyetin gerçekleştiği belirlenmiştir. Hizmetin gerçekleşmesi için yerine getirilen temel faaliyetler aşağıdaki gibidir.

- Rezervasyon alınması ve işlemlerinin yapılması,

- Müşterilerin otele kayıt işlemleri,

- Otel çıkış işlemleri, fatura ve tahsili,

- Müş̧eri hesaplarının tutulması,

- Oda anahtarlarını muhafaza etmek,

- Müşteri ve çalışanlara telefona hizmeti vermek

- Müşteri ile ilgili sorunların, şikayetlerin, beklentilerin dinlenmesi veya çözümüne yardım etmek

- Müşterilerin karşı1lanması,

- Dolu ve boş odaların, temizliği ve düzenlenmesi,

- Odaların kontrolü,

- Odaların durumu ile ilgili rapor hazırlamak ve ilgili birimlere bilgi vermek,

- Genel alanların temizliği (plaj ve restoran dahil)

- Menü ve reçetelerin hazırlanması,

- Yiyeceklerin pişirilmesi,

- Açık büfenin hazırlanması,

- Açı büfenin kaldırılması,

- Masaların hazırlanması,

- Yıkamadan sonra servis malzemelerinin yerleştirilmesi ve kurulanması,

- Servisin kaldirilmasi,

- Siparişin alınması ve verilmesi,

- Servis malzemelerinin yıkanması,

- Tüm mutfak malzemelerinin depolanmas1,

- Yemek öncesinde büfelerde kullanılacak 1sıtıcıları, soğutucuları, hazır hale getirmek ve servis sirasinda kontrol edilmesi,

\subsubsection{Faaliyet Merkezlerinin Belirlenmesi}

Faaliyet merkezleri diğer bir ifade ile maliyet havuzları ve bu merkezlerde gerçekleşen faaliyetler aşağıdaki gibi oluşturulmuştur.

- Önbüro Faaliyetleri

$\checkmark$ Rezervasyon alınması ve işlemlerinin yapılması,

$\checkmark$ Müşterilerin otele kayıt işlemleri,

$\checkmark$ Otel çıkış işlemleri, fatura ve tahsili,

$\checkmark$ Müşteri hesaplarının tutulması,

$\checkmark$ Oda anahtarlarını muhafaza etmek,

$\checkmark$ Müşteri ve çalışanlara telefona hizmeti vermek

$\checkmark$ Müşteri ile ilgili sorunların, şikayetlerin, beklentilerin dinlenmesi veya çözümüne yardım etmek

$\checkmark$ Müşterilerin karşılanması,

$\checkmark$ Günlük doluluk ve gelir raporlarının hazırlanması,

$\checkmark$ Müşterilerin ve eşyalarının odalara yerleştirilmesi

- Kat Hizmetleri Faaliyetleri

$\checkmark$ Dolu ve boş odaların, temizliği ve düzenlenmesi,

$\checkmark$ Odaların kontrolü,

$\checkmark$ Odaların durumu ile ilgili rapor hazırlamak ve ilgili birimlere bilgi vermek,

$\checkmark$ Genel alanların temizliği (plaj ve restoran dahil)

- Mutfak Hizmetleri Faaliyetleri

$\checkmark$ Menü ve reçetelerin hazırlanması,

$\checkmark$ Yiyeceklerin pişirilmesi,

$\checkmark$ Açık büfenin hazırlanmas,

$\checkmark \quad$ Açık büfenin kaldırılması 
- Servis Hizmetleri Faaliyetleri

$\checkmark$ Masaların hazırlanması,

$\checkmark$ Yıkamadan sonra servis malzemelerinin yerleştirilmesi ve kurulanması,

$\checkmark$ Servisin kaldırılması,

$\checkmark$ Siparişin alınması ve verilmesi,

- Bulaşıkhane Hizmetleri Faaliyetleri

$\checkmark$ Servis malzemelerinin y1kanması,

$\checkmark$ Tüm mutfak malzemelerinin depolanması,

$\checkmark$ Yemek öncesinde büfelerde kullanılacak 1sıtıcıları, soğutucuları, hazır hale getirmek ve servis sirasinda kontrol edilmesi,

Diğer faaliyet merkezleri ise, animasyon, hamam-sauna ve plaj-havuz hizmetleri faaliyetleridir.

İşletmedeki ortak faaliyetler ise, park-bahçe, güvenlik, yönetim, teknik servis, bina amortismanı, telefon, elektrik ve su giderlerinden oluşmaktadır.

İşletmedeki faaliyetler, faaliyet düzeyleri itibariyle aşağıdaki gibidir ve ilgili oldukları düzeylere uygun maliyet sürücüleri kullanılarak ürünlere yüklenir.

Hizmet birimleri düzeyindeki faaliyetler: Önbüro maliyetleri, kat hizmetleri maliyetleri, bulaşıkhane maliyetleri.

Hizmet partileri düzeyindeki faaliyetler: Mutfak maliyetleri ve servis maliyetleri.

Hizmet düzeyindeki faaliyetler: Örnek işletmemizde tek bir hizmet çeşidi yani herşey dahil sistem uygulanmaktadır. Ancak müşteri isteklerine bağlı olarak özellikle yardımcı hizmet faaliyetlerinde değişiklik yapilabilmektedir.

Tesis düzeyindeki faaliyetler: Park-bahçe, teknik servis, bina amortismanı, telefon, elektrik ve su giderleridir.

\subsubsection{Kaynak Maliyetlerinin ve Kaynak Sürücülerinin Belirlenmesi}

İşletme yöneticileri ile yapılan görüşmelerden, büyük defterden ve raporlardan elde edilen bilgiler Tablo 4'te verilmiştir.

Tablo 4: Kaynak Maliyetleri ve Kaynak Sürücüleri

\begin{tabular}{|l|l|r|}
\hline \multicolumn{1}{|c|}{ Kaynaklar } & \multicolumn{1}{|c|}{ Kaynak Sürücü } & \multicolumn{1}{c|}{ Tutar(TL) } \\
\hline Ön Büro Bölümü Personel Ücretleri & Ücret Bordrosu & $67.553,44$ \\
\hline Kat Hizmetleri Bölümü Personel Ücretleri & Ücret Bordrosu & $120.240,00$ \\
\hline Mutfak Bölümü Personel Ücretleri & Ücret Bordrosu & $134.803,95$ \\
\hline Bulaşıkhane Bölümü Personel Ücretleri & Ücret Bordrosu & $29.733,77$ \\
\hline Servis (restoran ve barlar) Bölümü Personel Ücretleri & Ücret Bordrosu & $178.262,79$ \\
\hline Çamaşırhane Bölümü Personel Ücretleri & Ücret Bordrosu & $27.589,95$ \\
\hline Animasyon Bölümü Personel Ücretleri & Ücret Bordrosu & $58.721,86$ \\
\hline Teknik Servis Bölümü Personel Ücretleri & Ücret Bordrosu & $83.608,74$ \\
\hline Güvenlik Bölümü Personel Ücretleri & Ücret Bordrosu & $64.500,85$ \\
\hline Park-Bahçe Bölümü Personel Ücretleri & Ücret Bordrosu & $37.609,95$ \\
\hline Hamam-Sauna Bölümü Personel Ücretleri & Ücret Bordrosu & $4.031,30$ \\
\hline Ana Depo Bölümü Personel Ücretleri & Ücret Bordrosu & $13.026,00$ \\
\hline Satış-Pazarlama Bölümü Personel Ücretleri & Ücret Bordrosu & $27.007,40$ \\
\hline Yönetim Bölümü Personel Ücretleri & Ücret Bordrosu & $48.119,30$ \\
\hline Muhasebe Bölümü Personel Ücretleri & Ücret Bordrosu & $38.332,33$ \\
\hline İnsan Kaynakları Bölümü Personel Ücretleri & Ücret Bordrosu & $21.414,84$ \\
\hline Satın Alma Bölümü Personel Ücretleri & Ücret Bordrosu & $11.790,98$ \\
\hline Personel Yiyecek-İçecek & Personel Sayıs1 & $47.430,30$ \\
\hline Taşıma Giderleri & Personel Sayıs1 & $32.173,03$ \\
\hline Elektrik & kws & $33.225,68$ \\
\hline Şebeke & Otel \%deleri ortalamas1 ve personel sayls1 & $7.824,50$ \\
\hline Peyzaj ve Havuz, Çamaşırhane & Su saati ve makine litre & $11.591,67$ \\
\hline Telefon & kontur(1 kontur=0,072ytl) & $9.159,09$ \\
\hline Amortisman & m2, büyük defter bilgileri & $281.411,52$ \\
\hline
\end{tabular}




\begin{tabular}{|l|l|r|}
\hline Yiyecek & Tüketim raporları, teslim fişleri & $475.312,50$ \\
\hline İcecek & Tüketim raporları, teslim fişleri & $288.668,98$ \\
\hline Temizlik Malzemeleri & Tüketim raporları, teslim fişleri & $26.594,26$ \\
\hline Kırtasiye ve Basılı Formlar & Tüketim raporları, teslim fişleri & $6.756,06$ \\
\hline Kimyasal Malzemeler & Tüketim raporları, teslim fişleri & $12.803,03$ \\
\hline Buklet Malzemeler & Tüketim raporları, teslim fişleri & $4.530,30$ \\
\hline LPG & Litre.saati & $48.000,00$ \\
\hline Taşıt Akaryakıt & Benzin fişleri & $16.001,82$ \\
\hline Servis Malzemeleri & Tüketim raporları, teslim fişleri & $1.516,67$ \\
\hline Bakım-Onarım & Büyük defter & $7.090,91$ \\
\hline Yedek Parça & Tüketim raporları, teslim fişleri & $4.924,24$ \\
\hline Elektrik Malzemeleri & Tüketim raporları, teslim fişleri & $9.651,52$ \\
\hline Sıhhi Tesisat Malzemeleri & Tüketim raporları, teslim fişleri & $3.348,48$ \\
\hline Misafir Ağırlama & Otel içi fişler & $10.636,36$ \\
\hline TOPLAM & & $\mathbf{2 . 3 0 4 . 9 9 8 , 3 7}$ \\
\hline
\end{tabular}


İşletme giderlerinin veya belirtilen kaynakların, bölümlere göre dağıtımı aşağıdaki gibidir (Tablo 5)

\section{Tablo 5a: Giderlerin Dağıtımı}

\begin{tabular}{|c|c|c|c|c|c|c|c|c|c|c|c|c|c|c|c|c|c|c|c|c|c|c|c|c|}
\hline Böllüler & $\begin{array}{l}\text { Personel } \\
\text { Ücretteri }\end{array}$ & $\begin{array}{c}\begin{array}{c}\text { Personel } \\
\text { Yiyecek }\end{array} \\
\text { Yot }\end{array}$ & 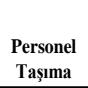 & Elektrik & $\begin{array}{c}\text { Su } \\
\text { (Sebeke) }\end{array}$ & $\begin{array}{c}\text { Personel } \\
\text { Su }\end{array}$ & $\begin{array}{c}\text { Peyzaj ve } \\
\text { Havuz, } \\
\text { Camaşrhan*** }\end{array}$ & Illetişim & LPG & Amortisman & Yiyecek & Ị̇ecek & $\begin{array}{l}\text { Kirtasiye } \\
\text { ve Bastl } \\
\text { Formlar }\end{array}$ & $\mid \begin{array}{c}\text { Temizlik } \\
\text { Malzemesi }\end{array}$ & $\begin{array}{l}\text { Kimyasal } \\
\text { Malzeme }\end{array}$ & $\begin{array}{l}\text { Yedek } \\
\text { Parça }\end{array}$ & $\begin{array}{c}\text { Buklet } \\
\text { Malzemeler }\end{array}$ & $\begin{array}{c}\text { Tasst } \\
\text { Akaryakt }\end{array}$ & $\begin{array}{c}\text { Servis } \\
\text { Malzemesi }\end{array}$ & $\begin{array}{l}\text { Bakm- } \\
\text { Onarmm }\end{array}$ & $\begin{array}{c}\text { Elektrik } \\
\text { Malzemesi }\end{array}$ & $\begin{array}{l}\text { Sithhi } \\
\text { Tesisat }\end{array}$ & $\begin{array}{c}\text { Misafir } \\
\text { Ağrrlama }\end{array}$ & Toplam \\
\hline Ön Büro & $67.553,44$ & $2.908,46$ & $1.972,87$ & 129,89 & & 95,96 & & 921,81 & & 836,26 & & & 675,61 & & & & & & & 354,55 & 241,29 & & & $75.690,14$ \\
\hline \begin{tabular}{|l|} 
Kat Hizmetleri \\
\end{tabular} & $120.240,00$ & $8.949,11$ & $6.070,38$ & $\begin{array}{ll}27.276,75 \\
\end{array}$ & $\begin{array}{l}5.007,68 \\
\end{array}$ & 295,26 & & & & $202.981,13$ & & & 337,8 & \begin{tabular}{ll|l}
$5.318,86$ \\
\end{tabular} & & $2.092,80$ & $4.530,30$ & & & & $3.233,26$ & 837,13 & & $387.170,46$ \\
\hline Mutfak & $\begin{array}{l}134.803,95 \\
\end{array}$ & $5.593,20$ & $3.793,99$ & 779,34 & 312,98 & 184,54 & & & $4.800,00$ & $7.870,71$ & $475.312,50$ & & 67,56 & & & 246,21 & & & & $2.127,27$ & 965,15 & 167,43 & & \begin{tabular}{ll|}
$637.024,83$ \\
\end{tabular} \\
\hline Bulaşikhane & \begin{tabular}{|l|l|}
$29,733,77$ \\
\end{tabular} & $1.789,82$ & $1.214,08$ & 346,37 & 938,94 & 59,05 & & & & 430,43 & & & 67,56 & \begin{tabular}{|l|}
$10.637,70$ \\
\end{tabular} & & 590,91 & & & & & 482,58 & 334,85 & & $46.626,06$ \\
\hline $\begin{array}{l}\text { Servis } \\
\text { (restoran ve } \\
\text { barlar) }\end{array}$ & $178.262,79$ & $11.186,39$ & $7.587,98$ & 151,54 & & 369,09 & & & & $17.053,21$ & & $288.668,98$ & 67,56 & & & 246,21 & & & $1.516,67$ & & 965,15 & & & $506.075,56$ \\
\hline Çamaşrnhane & $27.589,95$ & $1.789,82$ & $1.214,08$ & 649,45 & & 59,05 & $9.425,00$ & & $43.200,00$ & \begin{tabular}{|l|}
$5.560,30$ \\
\end{tabular} & & & 67,56 & \begin{tabular}{|l|}
$10.637,70$ \\
\end{tabular} & $5.121,21$ & 640,16 & & & & $1.418,18$ & 965,14 & $1.506,81$ & & $109.844,44$ \\
\hline \begin{tabular}{|l|} 
Animasyon \\
\end{tabular} & $58.721,86$ & $1.789,82$ & $1.214,08$ & 865,93 & & 59,05 & & & & $5.121,21$ & & & 67,56 & & & & & & & $1.772,73$ & \begin{tabular}{|l|l|}
$1.447,73$ \\
\end{tabular} & & & $71.059,97$ \\
\hline Teknik Servis & $83.608,74$ & $3.579,65$ & $2.428,15$ & 519,56 & & 118,11 & & 85,09 & & 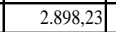 & & & 135,12 & & & 246,21 & & & & & \begin{tabular}{|l|l|l|}
144,77 \\
\end{tabular} & & & $\begin{array}{l}93.763,63 \\
\end{array}$ \\
\hline Güvenlik & $\begin{array}{ll}64.500,85 \\
\end{array}$ & $2.237,28$ & $1.517,60$ & & & 73,82 & & & & \begin{tabular}{l|l|l|}
$4.925,98$ \\
\end{tabular} & & & 135,12 & & & & & & & & & & & $73.390,62$ \\
\hline \begin{tabular}{|l|} 
Park-Bahçe \\
\end{tabular} & $\begin{array}{ll}37.609,95 \\
\end{array}$ & $2.237,28$ & $1.517,60$ & 216,48 & & 73,82 & $2.166,67$ & & & $1.276,36$ & & & 135,12 & & & 123,11 & & $1.918,48$ & & & 482,58 & 334,85 & & $48.092,29$ \\
\hline Hamam-Sauna & $4.031,30$ & 223,73 & 151,76 & 21,65 & & 7,38 & & & & $1.003,52$ & & & 67,56 & & & 246,21 & & & & & & & & $5.753,11$ \\
\hline \begin{tabular}{|l|} 
Ana Depo \\
\end{tabular} & $13.026,00$ & 671,18 & 455,27 & $1.082,41$ & & 22,14 & & & & \begin{tabular}{l|l}
$10.035,16$ \\
\end{tabular} & & & 270,25 & & & & & & & & & & & $25.562,42$ \\
\hline Havuz & & & & 129,89 & & & & & & \begin{tabular}{ll|l|l|l|l|l|}
3.1638 \\
\end{tabular} & & & & & $7.681,82$ & $\begin{array}{l}492,42 \\
\end{array}$ & & & & & 241,29 & $\begin{array}{l}167,43 \\
\end{array}$ & & \begin{tabular}{ll|l}
$11.876,72$ \\
\end{tabular} \\
\hline Plaj & & & & 32,47 & & & & & & & & & & & & & & & & & & & & 32,47 \\
\hline \begin{tabular}{|l|} 
Genel Bina \\
\end{tabular} & & & & 519,55 & & & & & & $\begin{array}{l}14.757,59 \\
\end{array}$ & & & & & & & & & & & & & & $15.277,14$ \\
\hline \begin{tabular}{|l|} 
Lojman Gider \\
\end{tabular} & & & & & & & & & & $\begin{array}{ll}1.213,33 \\
\end{array}$ & & & & & & & & & & & 482,58 & & & \begin{tabular}{ll|}
$1.695,92$ \\
\end{tabular} \\
\hline TOPLAM & $819.682,60$ & \begin{tabular}{|l|}
$42.955,74$ \\
\end{tabular} & $29.137,84$ & $32.721,28$ & $6.259,60$ & $1.417,27$ & 11.591,67 & $1.006,90$ & $48.000,00$ & \begin{tabular}{|l|}
$279.127,30$ \\
\end{tabular} & $4775.312,50$ & $288.668,98$ & $2.094,38$ & $26.594,26$ & \begin{tabular}{|l|}
$12.803,03$ \\
\end{tabular} & $4.924,24$ & $4.530,30$ & $1.918,48$ & \begin{tabular}{|c|}
$1.516,67$ \\
\end{tabular} & $5.672,73$ & $9.651,52$ & $3.348,50$ & & $2.108 .935,78$ \\
\hline
\end{tabular}

\section{Tablo 5b: Giderlerin Dağıtımı}

\begin{tabular}{|c|c|c|c|c|c|c|c|c|c|c|c|c|c|c|c|c|c|c|c|c|c|c|c|c|}
\hline Bölümler & $\begin{array}{l}\text { Personel } \\
\text { Ücretleri }\end{array}$ & $\begin{array}{l}\text { Personel } \\
\text { Yiyecek }\end{array}$ & $\begin{array}{c}\text { Personel } \\
\text { Taşima }\end{array}$ & Elektrik & $\begin{array}{c}\text { Su } \\
\text { (Sebeke) }\end{array}$ & $\begin{array}{c}\text { Personel } \\
\text { Su }\end{array}$ & \begin{tabular}{|c|}
$\begin{array}{c}\text { Peyzaj ve } \\
\text { Havuzz } \\
\text { Camaşrnhane* }\end{array}$ \\
\end{tabular} & Illetişim & LPG & Amortisman & & & \begin{tabular}{|c|} 
Krrtasiye \\
ve Baslit \\
Formlar
\end{tabular} & $\begin{array}{c}\text { Temizlik } \\
\text { Malzemesi }\end{array}$ & \begin{tabular}{|l|}
$\begin{array}{l}\text { Kimyasal } \\
\text { Mazeme }\end{array}$ \\
\end{tabular} & $\begin{array}{l}\text { Yedek } \\
\text { Parça } \\
\end{array}$ & $\begin{array}{c}\text { Buklet } \\
\text { Malzemeler }\end{array}$ & $\begin{array}{c}\text { Tastit } \\
\text { Akaryaktt }\end{array}$ & $\begin{array}{c}\text { Servis } \\
\text { Malzemesi }\end{array}$ & $\begin{array}{c}\text { Bakim- } \\
\text { Onarm } \\
\end{array}$ & \begin{tabular}{|c|c}
$\begin{array}{c}\text { Elektrik } \\
\text { Malzemesi }\end{array}$ \\
\end{tabular} & $\begin{array}{c}\text { Sthhi } \\
\text { Tesisat }\end{array}$ & \begin{tabular}{|c|}
$\begin{array}{c}\text { Misafiri } \\
\text { Ağrrama }\end{array}$ \\
\end{tabular} & Toplam \\
\hline & & & & & & & & & & & YIYECEK & IICECEEK & & & & & & & & & & & & \\
\hline $\begin{array}{l}\text { Saths- } \\
\text { Pazarlamaa }\end{array}$ & $27.007,40$ & 671,18 & 455,28 & 108,24 & & 22,14 & & $3.882,09$ & & 245,96 & & & 810,73 & & & & & $4.353,03$ & & & & & $3.722,73$ & $41.278,78$ \\
\hline Yönetim & $48.119,30$ & \begin{tabular}{|l|l|}
$1.118,64$ \\
\end{tabular} & \begin{tabular}{|l|}
758,8 \\
\end{tabular} & 216,48 & & 36,91 & & \begin{tabular}{|l|l|l|}
$2.49,25$ \\
\end{tabular} & & \begin{tabular}{|l|l|}
$1.065,83$ \\
\end{tabular} & & & \begin{tabular}{|c|c|}
675,61 \\
\end{tabular} & & & & & \begin{tabular}{|c|}
$5.377,27$ \\
\end{tabular} & & & & & \begin{tabular}{|c|}
$6.913,63$ \\
\end{tabular} & $66.721,72$ \\
\hline Muhasebe & $38.332,33$ & \begin{tabular}{ll|}
$1.566,09$ \\
\end{tabular} & 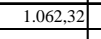 & $\begin{array}{ll}69,27 \\
6\end{array}$ & & $\begin{array}{l}51,67 \\
\end{array}$ & & \begin{tabular}{|l|l|}
92,18 \\
\end{tabular} & & $\begin{array}{l}655,89 \\
6\end{array}$ & & & $\begin{array}{l}2.499,74 \\
\end{array}$ & & & & & \begin{tabular}{l|l|}
$1.024,24$ \\
\end{tabular} & & $\begin{array}{l}709,09 \\
\end{array}$ & & & & $\begin{array}{l}46.062,83 \\
4\end{array}$ \\
\hline $\begin{array}{l}\text { Insann } \\
\text { Kaynakları }\end{array}$ & $21.414,84$ & 671,18 & 455,28 & 77,93 & & 22,14 & & 121,96 & & 163,97 & & & 337,8 & & & & & & & 354,55 & & & & $23.619,65$ \\
\hline Satin Alma & \begin{tabular}{|l|}
$11.790,98$ \\
\end{tabular} & 447,46 & 303,52 & 32,47 & & $\begin{array}{l}4,76 \\
\end{array}$ & & \begin{tabular}{|c|}
$1.616,71$ \\
\end{tabular} & & $\begin{array}{l}152,57 \\
\end{array}$ & & & 337,8 & & & & & \begin{tabular}{|l|l|}
$3.328,79$ \\
\end{tabular} & & \begin{tabular}{l|l|l}
354,55 \\
\end{tabular} & & & & \begin{tabular}{|l|l|}
$18.379,61$ \\
\end{tabular} \\
\hline TOPLAM & 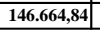 & $\begin{array}{l}4.474,56 \\
\end{array}$ & $3.035,19$ & 504,4 & & 147,63 & & \begin{tabular}{|c|c|c|c|}
$8.152,19$ \\
\end{tabular} & & $2.284,22$ & & & \begin{tabular}{|l|l}
$4.661,68$ \\
.4
\end{tabular} & & & & & 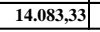 & & 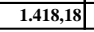 & & & $10.636,36$ & $196.062,59$ \\
\hline
\end{tabular}


Giderlerin genel dağıtımından sonra, teknik servis, lojman giderleri ve çamaşırhane bölümünün giderlerini hizmet maliyetinin oluşmasında direkt etkili olduklarından dolayı ilgili bölümlere dağıtma ihtiyacı ortaya çıkmaktadır.

Tablo 6: Teknik Servis, Lojman ve Çamaşırhane Giderlerinin Hizmet Birimlerine Yüklenmesi

\begin{tabular}{|l|r|r|r|r|r|}
\hline \multicolumn{1}{|c|}{ Bölümler } & $\begin{array}{r}\text { Giderler } \\
\text { Toplamı (TL) }\end{array}$ & $\begin{array}{c}\text { Teknik Servis (bakım } \\
\text { Onarım Kartları) (TL) }\end{array}$ & $\begin{array}{c}\text { Çamaşırhane } \\
\text { (Parça Sayısı) } \\
\text { (TL) }\end{array}$ & $\begin{array}{c}\text { Lojman } \\
\text { (Personel } \\
\text { SayısI) } \\
\text { (TL) }\end{array}$ & $\begin{array}{c}\text { Dağıtım } \\
\text { Sonrası } \\
\text { Toplam(TL) }\end{array}$ \\
\hline Ön Büro & $75.690,14$ & $1.875,27$ & & & $77.565,41$ \\
\hline Kat Hizmetleri & $387.170,46$ & $28.129,09$ & $102.877,73$ & & $518.177,28$ \\
\hline Mutfak & $637.024,83$ & $5.625,82$ & & $1.352,65$ & $644.003,29$ \\
\hline Bulaşıkhane & $46.626,06$ & $11.251,64$ & & 601,18 & $58.478,87$ \\
\hline Servis (restoran ve barlar) & $506.075,56$ & 937,64 & $25.719,43$ & $2.555,00$ & $535.287,63$ \\
\hline Çamaşırhane & $109.844,44$ & $18.752,73$ & & & \\
\hline Animasyon & $71.059,97$ & $10.314,00$ & & & $81.373,97$ \\
\hline Teknik Servis & $93.763,63$ & 937,64 & & & 937,64 \\
\hline Park-Bahçe & $48.092,29$ & 937,64 & & & $49.029,93$ \\
\hline Hamam-Sauna & $5.753,11$ & 937,64 & & & $6.690,74$ \\
\hline Havuz & $11.876,72$ & $4.688,18$ & & & $16.564,90$ \\
\hline Plaj & 32,47 & 0,00 & & & \\
\hline Genel Bina & $15.277,14$ & $1.875,27$ & & & $17.152,42$ \\
\hline Lojman Gider & $1.695,91$ & $2.812,91$ & & & \\
\hline TOPLAM & $\mathbf{2 . 1 0 8 . 9 3 5 , 7 8}$ & $\mathbf{8 9 . 0 7 5 , 4 5}$ & $\mathbf{1 2 8 . 5 9 7 , 1 6}$ & $\mathbf{4 . 5 0 8 , 8 2}$ & $\mathbf{2 . 0 0 5 . 2 9 4 , 5 5}$ \\
\hline
\end{tabular}

Tablo 7: Teknik Servis, Lojman ve Çamaşırhane Giderlerinin İdari Birimlerine Yüklenmesi

\begin{tabular}{|l|r|r|r|r|r|}
\hline \multicolumn{1}{|c|}{ Bölümler } & \multicolumn{1}{c|}{$\begin{array}{c}\text { Giderler } \\
\text { Toplamı } \\
\text { (TL) }\end{array}$} & $\begin{array}{c}\text { Teknik Servis (bakım } \\
\text { Onarım Kartları) } \\
\text { (TL) }\end{array}$ & $\begin{array}{c}\text { Çamaşırhane } \\
\text { (Parça } \\
\text { Sayısı) (TL) }\end{array}$ & $\begin{array}{c}\text { Lojman } \\
\text { (Personel } \\
\text { SayısI) } \\
\text { (TL) }\end{array}$ & $\begin{array}{c}\text { Dağıtım } \\
\text { Sonrası } \\
\text { Toplam } \\
\text { (TL) }\end{array}$ \\
\hline Satı̧-Pazarlama & $41.278,78$ & 0,00 & & & $41.278,78$ \\
\hline Yönetim & $66.721,72$ & 937,64 & & & $67.659,35$ \\
\hline Muhasebe & $46.062,83$ & 937,64 & & & $47.000,47$ \\
\hline Ana Depo & $25.562,42$ & $2.812,91$ & & & $28.375,33$ \\
\hline İnsan Kaynakları & $23.619,66$ & & & & $23.619,66$ \\
\hline Güvenlik & $73.390,62$ & & & & $73.390,62$ \\
\hline Satın Alma & $18.379,61$ & & & & $18.379,61$ \\
\hline TOPLAM & $\mathbf{2 9 5 . 0 1 5 , 6 3}$ & $\mathbf{4 . 6 8 8 , 1 8}$ & & & $\mathbf{2 9 9 . 7 0 3 , 8 2}$ \\
\hline
\end{tabular}

\subsubsection{Kaynakların Faaliyetlere Yüklenmesi ve Faaliyet Maliyetlerinin Hesaplanması}

\section{1- Önbüro Faaliyet Merkezi Maliyetinin Hesaplanması}

Önbüro bölümünde kaynakların faaliyetlere yüklenmesinde, bir birim işlem için harcanan zaman temel alınmaktadır ve harcanan zaman azaldıkça, bekleme süreleri azalacağından dolayı, müşteri memnuniyeti de artacaktır. Önbüroda işlemlerin zamanında yapılması (TZÜ), çalışanlara sürekli eğitim verilmesi, TZÜ ve toplam kalitenin yükseltilmesi, müşteri ihtiyaçlarının karşılanması ve diğer bölümlerle etkili koordinasyonla müşteri memnuniyetinin maksimize edilmesini sağlamaktadır.

Önbüro faaliyetleri incelendiğinde, faaliyetlerin direkt olarak müşteriye ve hizmete değer katan faaliyetler olduğu görülmektedir. Rezervasyon alınması ve işlemlerinin yapılması faaliyetinde, kişi ve grup 
rezervasyonları için harcanan zamanın ölçülememesi; günlük doluluk ve gelir raporlarının hazırlanması faaliyetinde harcanan zamanın kişi ve gruplara bağlı olarak değişmemesi; müşterilerin ve eşyalarının odalara yerleştirilmesi faaliyetinde harcanan zamanının ölçülememesinden dolayı bu faaliyetlerin maliyetine sadece, faaliyetleri yerine getiren kişilerin ücretleri, taşıma gideri ve yiyecek gideri yüklenmiştir. Faaliyetlerin maliyeti incelendiğinde, müşteri şikayetlerinin işletmeye artı bir maliyeti vardır. Bu nedenle işletmenin, kaliteli hizmete önem vererek, müşteri ihtiyaç ve beklentilerini hızlı bir şekilde karşılayabilmesi için bu faaliyete harcanan zamanı k1saltabilir ve maliyetini azaltabilir.

Tablo 8: Önbüro Faaliyetlerinin Maliyetlerinin Hesaplanması

\begin{tabular}{|c|c|c|c|c|c|}
\hline Faaliyetler & $\begin{array}{l}\text { İşlem } \\
\text { Sayısı } \\
\text { (kişi) }\end{array}$ & $\begin{array}{c}\text { İşlem } \\
\text { Süresi } \\
\text { (saniye) } \\
\end{array}$ & $\begin{array}{l}\text { Toplam } \\
\text { İşlem } \\
\text { Süresi } \\
\end{array}$ & $\begin{array}{c}\text { Faaliyet } \\
\text { Oranı } \\
(\%)\end{array}$ & $\begin{array}{c}\text { Faaliyetin } \\
\text { Maliyeti } \\
\text { (TL) }\end{array}$ \\
\hline $\begin{array}{l}\text { Rezervasyon alınması ve } \\
\text { işlemlerinin yapılması }\end{array}$ & 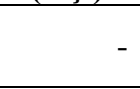 & -1 & 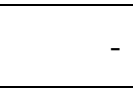 & - & 11.895 .45 \\
\hline Müşterilerin otele kayıt işlemleri & 2.208 & 120 & 264.960 & 31,85 & $16.436,76$ \\
\hline Otel çıkış işlemleri, fatura ve tahsili & 980 & 360 & 352.800 & 42,41 & 21.885 .90 \\
\hline $\begin{array}{l}\text { Müşteri ve çalışanlara telefon hizmeti } \\
\text { vermek }\end{array}$ & 2.208 & 15 & 33.120 & 3,98 & $2.054,59$ \\
\hline $\begin{array}{l}\text { Müşteri ile ilgili sorunların, şikayetlerin, } \\
\text { beklentilerin dinlenmesi veya çözümüne } \\
\text { yardım etmek } \\
\text { (Aylı toplam müşterinin \%20'nin } \\
\text { işletmeden beklenti ve şikayetleri olduğu } \\
\text { öngörülmüştür) }\end{array}$ & 441,6 & 360 & 158.976 & 19,11 & $9.862,06$ \\
\hline Müşterilerin karşılanmas1 & 2.208 & 10 & 2.080 & 2,65 & $1.369,73$ \\
\hline $\begin{array}{l}\text { Günlük doluluk ve gelir raporlarının } \\
\text { hazırlanması }\end{array}$ & 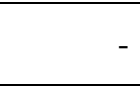 & - & 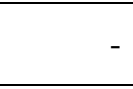 & - & $6.418,67$ \\
\hline $\begin{array}{l}\text { Müşterilerin ve eşyalarının odalara } \\
\text { yerleştirilmesi }\end{array}$ & & & & & $7.638,25$ \\
\hline Önbüro Faaliyet Merkezi Maliyeti & $10.253,6$ & 865 & 831,936 & 100 & $77.565,41$ \\
\hline
\end{tabular}

\section{2-Kat Hizmetleri Faaliyet Merkezi Maliyetinin Hesaplanması}

Kat hizmetleri faaliyetlerinde yer alan genel alanların temizliği kat hizmetlerine bağlı meydancılar tarafından yerine getirilmektedir. Ancak meydancıların faaliyet maliyetlerinin faaliyet sürücüsü farklı olduğundan dolayı ayrı bir faaliyet merkezi olarak ele alınması gerekmektedir.

Kat hizmetlerinde oda temizliği faaliyetinde çalışan 24 kişi vardır ve 1 oda, 1 kişi tarafından 20 dakikada temizlenmek durumundadır. Buna göre 350 odanın standart toplam temizleme süresi 7000 dakikadır. Odaların kontrolü faaliyetini ise 3 kişi yerine getirmektedir ve 1 odanın standart kontrol süresi 3 dakikadır. Standart toplam oda kontrol süresi ise 1.050 dakikadır.

Standart süreye göre dolu ve boş odaların temizlenmesi faaliyetinde, maliyet 308.466,14 TL dir. Ancak çalışan kişi sayısı ve çalışma süreleri dikkate alınarak faaliyetin maliyeti hesaplandığında, maliyet 330.597,36 TL olacaktır. Bu durumda örnek işletmede bu faaliyetin gerçekleşmesi sırasında 4.520 dakikalık bir boşa geçen zaman ortaya çıkacaktır. Bu da işletmenin bu faaliyet için fazla personel çalıştırmasından kaynaklanmaktadır. Dolu ve boş odaların temizliği faaliyeti maliyetinin fazla olmasından dolayı da, kontrol ve raporlama faaliyetlerinin maliyetlerinde bir azalma göze çarpmaktadır ki bu da yanlış kararlar almaya neden olabilir. Çünkü standart süreye yaklaşılması halinde, kontrol ve raporlama için katlanılan maliyetin daha yüksek olduğu görülmektedir. Sonuç itibari ile yönetimsel olarak kontrol ve denetimin yapılmaması oda temizliğinde standardın yakalanması halinde işçi sayısında bir azalma, bununla birlikte oda kontrolü ve rapor hazırlama faaliyetlerini gerçekleştirmekte olan yönetimin maliyetini de azalacaktır. 
Tablo 9: Kat Hizmetleri Faaliyetlerinin Maliyetlerinin Hesaplanması (\%100 doluluk)

\begin{tabular}{|l|r|r|r|r|}
\hline \multicolumn{1}{|c|}{ Faaliyetler } & \multicolumn{1}{|c|}{$\begin{array}{c}\text { Oda } \\
\text { Sayısı }\end{array}$} & $\begin{array}{c}\text { Standart } \\
\text { Temizleme } \\
\text { Süresi } \\
\text { dakika) }\end{array}$ & $\begin{array}{c}\text { Faaliyet } \\
\text { Oranı } \\
(\%)\end{array}$ & Faaliyetin Maliyeti (TL) \\
\hline $\begin{array}{l}\text { Dolu ve boş odaların temizliği ve } \\
\text { düzenlenmesi }\end{array}$ & 350 & 7.000 & 82,94 & $308.466,14$ \\
\hline Odaların kontrolü & 350 & 1.050 & 12,44 & $46.269,92$ \\
\hline $\begin{array}{l}\text { Odaların durumu ile ilgili rapor } \\
\text { hazırlamak ve ilgili birimlere bilgi } \\
\text { vermek }\end{array}$ & 390 & 4,62 & $17.185,97$ \\
\hline Çamaşırhane Maliyeti & & & & $102.877,73$ \\
\hline $\begin{array}{l}\text { Kat Hizmetleri Faaliyet Merkezi } \\
\text { Maliyeti }\end{array}$ & $\mathbf{8 . 4 4 0}$ & $\mathbf{1 0 0}$ & $\mathbf{4 7 4 . 7 9 9 , 7 6}$ \\
\hline
\end{tabular}

Tablo 10: Gerçekleşen Kat Hizmetlerinin Faaliyetlerinin Maliyeti (\%70 doluluk)

\begin{tabular}{|c|c|c|c|c|c|c|c|}
\hline Faaliyetler & $\begin{array}{l}\text { Çalışan } \\
\text { Eleman }\end{array}$ & $\begin{array}{c}\text { Çalışma } \\
\text { Saati } \\
\text { (dakika) }\end{array}$ & $\begin{array}{c}\text { Fiili } \\
\text { Çalışma(dakika) }\end{array}$ & $\begin{array}{c}\text { Faaliyet } \\
\text { Oranı (\%) }\end{array}$ & $\begin{array}{c}\text { Faaliyetin } \\
\text { Maliyeti }\end{array}$ & $\begin{array}{c}\text { Boşa } \\
\text { Geçen } \\
\text { Zaman }\end{array}$ & $\begin{array}{c}\text { Boşa Geçen } \\
\text { Zaman } \\
\text { Maliyeti }\end{array}$ \\
\hline $\begin{array}{c}\text { Dolu ve boş odaların } \\
\text { temizliği ve } \\
\text { düzenlenmesi }\end{array}$ & 24 & 480 & 11.520 & 88,89 & $330.597,36$ & 4520 & $22.131,22$ \\
\hline Odaların kontrolü & 3 & 480 & 1.050 & 8,10 & $30.132,57$ & 0 & rapor hazırlama \\
\hline $\begin{array}{l}\text { Odaların durumu ile } \\
\text { ilgili rapor } \\
\text { hazırlamak ve ilgili } \\
\text { birimlere bilgi } \\
\text { vermek }\end{array}$ & & & 390 & 3,01 & $11.192,10$ & 0 & \\
\hline TOPLAM & & & 12.960 & 100 & $91.571,05$ & & \\
\hline
\end{tabular}

\section{Meydan Temizliği Faaliyet Merkezi}

Kat hizmetlerine bağlı olarak çalışan toplam 10 meydancı vardır ve bu kişiler işletmenin aşağıda belirtildiği gibi, restoran temizliği, plaj temizliği, havuz alanı temizliği, genel bina ve alanların temizliği faaliyetlerini yerine getirmektedirler.

Tablo 11: Meydan Temizliği Faaliyetlerinin Maliyetlerinin Hesaplanması

\begin{tabular}{|l|r|r|r|r|r|}
\hline \multicolumn{1}{|c|}{ Faaliyetler } & $\begin{array}{c}\text { Çalışılan } \\
\text { Süre } \\
\text { (saat) }\end{array}$ & Kişi sayısı & $\begin{array}{c}\text { Toplam } \\
\text { Çalışılan } \\
\text { Süre } \\
\text { (saat) }\end{array}$ & $\begin{array}{c}\text { Faaliyet } \\
\text { Oranı } \\
\text { (\%) }\end{array}$ & \multicolumn{1}{c|}{$\begin{array}{c}\text { Faaliyetin } \\
\text { Maliyeti (TL) }\end{array}$} \\
\hline Restoran temizliği & 2,5 & 2 & 5 & 6 & $2.711,10$ \\
\hline Plaj temizliği ve hazırlığı & 1,5 & 1 & 1,5 & 2 & 813,33 \\
\hline Havuz alanı temizliği & 0,5 & 1 & 0,5 & 1 & 271,11 \\
\hline Genel bina ve alan temizliği & 7,3 & 10 & 73,00 & 91 & $39.581,99$ \\
\hline TOPLAM & & & $\mathbf{8 0 , 0 0}$ & $\mathbf{1 0 0}$ & $\mathbf{4 3 . 3 7 7 , 5 3}$ \\
\hline
\end{tabular}

\section{3- Mutfak Hizmetleri Faaliyet Merkezi Maliyetinin Hesaplanması}

Mutfak hizmetlerinde yiyeceklerin hazırlanması faaliyetinde; sabah kahvaltısında 2 kişi gece toplam 16 işçilik saati, öğle yemeğinde 10 kişi toplam 40 işçilik saati, akşam yemeğinde 15 kişi toplam 90 işçilik saati, çay saati için ise 2 kişi toplam 2 iş̧̧ilik saati çalışmaktadır.

Açık büfenin hazırlanmasında, sabah kahvaltısı ve masaların hazırlanması için 2 kişi toplam 3 işçilik saati, öğle yemeği için 4 kişi toplam 2 işçilik saati, akşam yemeği için ise 4 kişi toplam 2 işçilik saati çalışmaktadır.

Açık büfenin kaldırılmasında, sabah kahvaltısı için 7 kişi toplam 3,5 işçilik saati, öğle yemeğinde 4 kişi toplam 2 işçilik saati, akşam yemeğinde ise yine 4 kişi toplam 2 işçilik saati çalışmaktadır. 
Açık büfenin hazırlanması ve kaldırılmasındaki işçilik oranlarında ve maliyetlerinde aşçıbaşı gibi yüksek işçilik maliyeti olanlar da aynı faaliyetler içerisinde dağıtımı yapılmıştır. Burada yapılması gereken maliyetleri etkileyebilecek yüksek ücretlilerin, büfelerin hazırlanması ve kaldırılmasında verilecek ağırlığın ayrıca tespit edilmesi gerekmektedir.

a)Yiyeceklerin Hazırlanması Faaliyet Maliyetinin Hesaplanması

Yiyeceklerin hazırlanması faaliyetinin maliyeti ile ilgili hesaplamalar tablo 12'de verilmiştir.

Tablo 12: Yiyeceklerin Hazırlanması Faaliyet Maliyetinin Hesaplanması

\begin{tabular}{|l|r|r|r|r|r|}
\hline \multicolumn{1}{|c|}{ Faaliyetler } & Çalışılan Saat & Çalışan kişi & $\begin{array}{c}\text { Toplam Çalışılan } \\
\text { Süre }\end{array}$ & $\begin{array}{c}\text { Faaliyet } \\
\text { Oranı(\%) }\end{array}$ & $\begin{array}{c}\text { Faaliyetin } \\
\text { Maliyeti (TL) }\end{array}$ \\
\hline Sabah kahvaltıs1 & 8 & 3 & 24 & 14,37 & $90.893,77$ \\
\hline Öğle yemeği & 4 & 11 & 44 & 26,35 & $166.638,58$ \\
\hline Akşam yemeği & 6 & 16 & 96 & 57,49 & $363.575,08$ \\
\hline Çay saati & 1 & 3 & 3 & 1,80 & $11.361,72$ \\
\hline TOPLAM & & & $\mathbf{1 6 7}$ & $\mathbf{1 0 0}$ & $\mathbf{6 3 2 . 4 6 9 , 1 5}$ \\
\hline
\end{tabular}

b)Açık Büfenin Hazırlanması Faaliyeti Maliyetinin Hesaplanması

Sabah kahvaltısı, öğle yemeği ve akşam yemeği açık büfelerinin hazırlanmasına ait hesaplamalar tablo 13 'de verilmiştir.

Tablo 13: Açık Büfenin Hazırlanması Faaliyeti Maliyetinin Hesaplanması

\begin{tabular}{|l|r|r|r|r|r|}
\hline \multicolumn{1}{|c|}{ Faaliyetler } & Çalışılan Saat & Çalışan kişi & $\begin{array}{c}\text { Toplam Çalışılan } \\
\text { Süre }\end{array}$ & $\begin{array}{c}\text { Faaliyet } \\
\text { Oranı(\%) }\end{array}$ & $\begin{array}{c}\text { Faaliyetin } \\
\text { Maliyeti (TL) }\end{array}$ \\
\hline Sabah kahvaltıs1 & 1,5 & 2 & 3 & 42,86 & $2.386,37$ \\
\hline Öğle yemeği & 0,5 & 4 & 2 & 28,57 & $1.590,92$ \\
\hline Akşam yemeği & 0,5 & 4 & 2 & 28,57 & $1.590,92$ \\
\hline Toplam & & & & $\mathbf{1 0 0}$ & $\mathbf{5 . 5 6 8 , 2 1}$ \\
\hline
\end{tabular}

c)Açık Büfenin Kaldırılması Faaliyeti Maliyetinin Hesaplanması

Tablo 14'de açık büfenin kaldırılması faaliyetinin maliyetine ait hesaplamalar verilmiştir

Tablo 14: Açık Büfenin Kaldırılması Faaliyeti Maliyetinin Hesaplanması

\begin{tabular}{|l|r|r|r|r|r|}
\hline \multicolumn{1}{|c|}{ Faaliyetler } & Çalışılan Saat & Çalışan kişi & $\begin{array}{c}\text { Toplam Çalışılan } \\
\text { Süre }\end{array}$ & $\begin{array}{c}\text { Faaliyet } \\
\text { Oranı(\%) }\end{array}$ & $\begin{array}{c}\text { Faaliyetin } \\
\text { Maliyeti (TL) }\end{array}$ \\
\hline Sabah kahvaltıs1 & 1,5 & 7 & 3,5 & 46,67 & $2.784,10$ \\
\hline Öğle yemeği & 0,5 & 4 & 2 & 26,67 & $1.590,92$ \\
\hline Akşam yemeği & 0,5 & 4 & 2 & 28,67 & $1.590,92$ \\
\hline TOPLAM & & & $\mathbf{7 , 5}$ & $\mathbf{1 0 0}$ & $\mathbf{5 . 9 6 5 , 9 4}$ \\
\hline
\end{tabular}

\section{Mutfak Hizmetleri Faaliyet Merkezi Maliyeti}

644.003,29

\section{4- Servis Hizmetleri Faaliyet Merkezi Maliyetinin Hesaplanması}

Servis hizmetlerinde masaların hazırlanması faaliyetinde, öğle yemeğinde 4 kişi toplam 4 işçilik saati, akşam yemeğinde yine 4 kişi toplam 4 işçilik saati çalışmaktadır.

Servis hizmetlerinde masaların hazırlanması ile ilgili faaliyetin maliyetinin hesaplanmasına ait bilgiler tablo 15 'teki gibidir. 
Tablo 15: Masaların Hazırlanması Faaliyeti Maliyetinin Hesaplanması

\begin{tabular}{|l|r|r|r|r|r|}
\hline \multicolumn{1}{|c|}{ Masaların hazırlanması } & Çalışılan Saat & Çalışan Kişi & $\begin{array}{c}\text { Toplam } \\
\text { Çalışılan } \\
\text { Süre } \\
\text { dakika) }\end{array}$ & $\begin{array}{c}\text { Faaliyet } \\
\text { Oran } \\
(\boldsymbol{\%})\end{array}$ & $\begin{array}{c}\text { Faaliyetin } \\
\text { Maliyeti (TL) }\end{array}$ \\
\hline Öğle yemeği & 1 & 4 & 240 & 5,32 & $11.762,47$ \\
\hline Akşam yemeği & 1 & 4 & 240 & 5,32 & $11.762,47$ \\
\hline TOPLAM & & & & & $\mathbf{2 3 . 5 2 4 , 9 4}$ \\
\hline
\end{tabular}

Yıkamadan sonra servis malzemelerinin kurulanması ve yerleştirilmesi faaliyetinde, çatal, kaşık, ve bıçakların kurulanmasında 2 kişi çalışmakta ve birim başına 5 sanayide faaliyeti yerine getirmektedirler. Bardakların kurulanmasında ise 2 kişi çalışmakta ve birim başına 7 saniyede faaliyeti yerine getirmektedirler.

Tablo 16: Servis Malzemelerinin Kurulanması ve Yerleştirilmesi Faaliyetleri Maliyetinin Hesaplanması

\begin{tabular}{|c|c|c|c|c|c|c|c|c|c|}
\hline Faaliyetler & $\begin{array}{l}\text { Parça } \\
\text { Sayısı }\end{array}$ & $\begin{array}{l}\text { Günlük } \\
\text { Müşteri }\end{array}$ & $\begin{array}{l}\text { Toplam } \\
\text { Parça } \\
\text { Sayısı }\end{array}$ & $\begin{array}{c}\text { Birim } \\
\text { Süre(saniye) }\end{array}$ & $\begin{array}{l}\text { Toplam } \\
\text { Süre } \\
\text { (dakika) }\end{array}$ & $\begin{array}{l}\text { Çalış̧an } \\
\text { Kişi } \\
\text { Sayısı }\end{array}$ & \begin{tabular}{|c|} 
Çalışılan \\
Toplam \\
Süre \\
(dakika)
\end{tabular} & $\begin{array}{c}\text { Faaliyet } \\
\text { oranı } \\
(\%)\end{array}$ & $\begin{array}{c}\text { Faaliyetin } \\
\text { Maliyeti } \\
\text { (TL) }\end{array}$ \\
\hline $\begin{array}{l}\text { Çatal, kaşık ve } \\
\text { bıçakların } \\
\text { kurulanması ve } \\
\text { yerleştirilmesi }\end{array}$ & 18 & 552 & 9.936 & 5 & 828 & 2 & 414 & 9,19 & $20.290,26$ \\
\hline $\begin{array}{c}\text { Bardakların } \\
\text { kurulanması ve } \\
\text { yerleştirilmesi }\end{array}$ & 6 & 552 & 3.312 & 7 & 386,4 & 2 & 193,2 & 4,29 & $9.468,79$ \\
\hline TOPLAM & & & & & & & & & $29.759,05$ \\
\hline
\end{tabular}

Servisin kaldırılması faaliyetinde 10 kişi, toplam 2,5 işçilik saati çalışmaktadır. Tablo 17 'de servis kaldırılması faaliyeti maliyetinin hesaplanması verilmiştir.

Tablo 17: Servisin Kaldırılması Faaliyeti Maliyetinin Hesaplanması

\begin{tabular}{|l|r|r|r|r|r|}
\hline \multicolumn{1}{|c|}{ Faaliyet } & \multicolumn{1}{|c|}{$\begin{array}{c}\text { Çalışan Kişi } \\
\text { Sayısı }\end{array}$} & $\begin{array}{c}\text { Çalışılan } \\
\text { Süre(dakika) }\end{array}$ & $\begin{array}{c}\text { Toplam } \\
\text { Çalışılan } \\
\text { Süre(dakika) }\end{array}$ & $\begin{array}{c}\text { Faaliyetin } \\
\text { Oranı }\end{array}$ & $\begin{array}{c}\text { Faaliyetin } \\
\text { Maliyeti (TL) }\end{array}$ \\
\hline Servisin Kaldırılması & 10 & 150 & 1500 & 33,28 & $73.515,45$ \\
\hline
\end{tabular}

Siparişin alınması ve verilmesi faaliyeti barlarda yerine getirilmektedir ve 4 barda toplam 4 kişi ve 32 işçilik saati çalışmaktadırlar.

Tablo 18: Servisin Alınması ve Verilmesi Faaliyeti Maliyetinin Hesaplanması

\begin{tabular}{|l|r|r|r|r|r|}
\hline Faaliyet & \multicolumn{1}{|c|}{$\begin{array}{c}\text { Çalışan Kişi } \\
\text { Sayısı }\end{array}$} & $\begin{array}{c}\text { Çalışılan } \\
\text { Süre(saat) }\end{array}$ & $\begin{array}{c}\text { Toplam } \\
\text { Çalısıllan } \\
\text { Süre } \\
\text { (dakika) }\end{array}$ & $\begin{array}{c}\text { Faaliyetin } \\
\text { Oranı(\%) }\end{array}$ & $\begin{array}{c}\text { Faaliyetin } \\
\text { Maliyeti (TL) }\end{array}$ \\
\hline Siparişin alınması ve verilmesi & & 8 & 1920 & 42,60 & $94.099,77$ \\
\hline
\end{tabular}




\section{5- Bulaşıkhane Hizmetleri Faaliyet Merkezi Maliyetinin Hesaplanması}

Bulaşıkhane hizmetlerinde gerçekleşen faaliyetlerin maliyetlerine ait hesaplamalar tablo 19'da verilmiştir.

Tablo 19: Bulaşıkhane Hizmetleri Faaliyet Merkezinin Maliyetinin Hesaplanması

\begin{tabular}{|c|c|c|c|c|c|c|c|}
\hline Faaliyetler & $\begin{array}{l}\text { Günlük } \\
\text { Kap } \\
\text { Sayısı }\end{array}$ & $\begin{array}{l}\text { Müşteri } \\
\text { Sayısı }\end{array}$ & $\begin{array}{c}\text { Toplam } \\
\text { Kap } \\
\text { Sayısı }\end{array}$ & $\begin{array}{c}\text { Faaliyetin } \\
\text { Süresi } \\
\text { (saniye) }\end{array}$ & $\begin{array}{c}\text { Toplam } \\
\text { Faaliyetin } \\
\text { Süresi(dakika) }\end{array}$ & $\begin{array}{c}\text { Faaliyet } \\
\text { Oranı(\%) }\end{array}$ & $\begin{array}{c}\text { Faaliyetin } \\
\text { Maliyeti } \\
\text { (TL) }\end{array}$ \\
\hline $\begin{array}{l}\text { Servis takımlarının } \\
\text { yıkamaya hazır hale } \\
\text { getirilmesi (çöpe } \\
\text { dökme, sudan } \\
\text { geçirme) }\end{array}$ & 11 & 552 & 6.072 & 8 & 809,6 & 28,50 & $16.665,90$ \\
\hline $\begin{array}{l}\text { Servis } \\
\text { malzemelerinin } \\
\text { boyutuna göre } \\
\text { ayrılması }\end{array}$ & 11 & 552 & 9.384 & 3 & 469,2 & 16,52 & $9.658,65$ \\
\hline $\begin{array}{l}\text { Makinalara } \\
\text { yerleştirilmesi }\end{array}$ & 17 & 552 & 9.384 & 2 & 312,8 & 11,01 & $6.439,10$ \\
\hline $\begin{array}{l}\text { Kazanların } \\
\text { yıkanması }\end{array}$ & & & & & 720 & 25,34 & $14.821,45$ \\
\hline $\begin{array}{l}\text { Tüm mutfak } \\
\text { malzemelerinin } \\
\text { porselen, cam, } \\
\text { paslanmaz çelik ve } \\
\text { diğer yiyecek- } \\
\text { içecek } \\
\text { malzemelerinin } \\
\text { depolanması }\end{array}$ & & & 9.384 & 3 & 469,2 & 16,52 & $9.658,65$ \\
\hline $\begin{array}{l}\text { Yemek öncesinde } \\
\text { büfelerde } \\
\text { kullanılacak } \\
\text { 1sitıciları, } \\
\text { soğutucuları, hazır } \\
\text { hale getirmek ve } \\
\text { servis sirasında } \\
\text { kontrol edilmesi } \\
\end{array}$ & & & & & 60 & 2,11 & $1.235,12$ \\
\hline TOPLAM & & & & & & 100 & $\mathbf{5 4 . 4 7 8 , 8 7}$ \\
\hline
\end{tabular}

\subsubsection{Faaliyet Maliyetlerinin Hizmet Birimine Yüklenmesi}

Faaliyet maliyetlerinin maliyet sürücülerine göre yüklenmesi aşağıdaki gibidir.

Tablo 20: Faaliyet Maliyetlerinin Hizmet Birimine Yüklenmesi

\begin{tabular}{|c|c|c|c|}
\hline Faaliyet Merkezi & $\begin{array}{c}\text { Faaliyetin } \\
\text { Maliyeti }\end{array}$ & Maliyet Sürücüsü & $\begin{array}{c}\text { Birim Hizmet } \\
\text { Maliyeti }\end{array}$ \\
\hline Önbüro & $77.565,41$ & Kalan Müşteri Sayısı:2.208 & 35,13 TL/Kişi \\
\hline Kat Hizmetleri & $474.799,76$ & Oda Sayıs1:7.350 & $64,60 \mathrm{TL} / \mathrm{Oda}$ \\
\hline Meydan & $43.377,52$ & Çalışma saati:2.400 & $18,07 \mathrm{Tl} / \mathrm{Saat}$ \\
\hline Mutfak & $644.003,29$ & Geceleme Say1s1: 16.560 & $38,89 \mathrm{TL} /$ Geceleme \\
\hline Servis & $535.287,63$ & Geceleme Say1s1:16.560 & $32,32 \mathrm{TL} /$ Geceleme \\
\hline Bulaşıkhane & $58.478,87$ & Kap Say1sı:745.200 & 0,078 TL/Kap \\
\hline Hamam-Sauna & $6.690,74$ & Geceleme Sayısı: 16.560 & $0,40 \mathrm{TL} /$ Geceleme \\
\hline Animasyon & $81.373,97$ & Geceleme Say1s1:16.560 & 4,91 TL/Geceleme \\
\hline Havuz-Plaj & $16.597,37$ & Geceleme Sayıs1: 16.560 & 1,00 TL/Geceleme \\
\hline Park-Bahçe & $49.029,93$ & Çalışma Saati:2.400 & $20,43 \mathrm{TL} / \mathrm{Saat}$ \\
\hline Genel Bina & $17.152,42$ & Geceleme Sayısı: 16.560 & $10,40 \mathrm{TL} /$ Geceleme \\
\hline Teknik Servis & 937,64 & Geceleme Sayıs1: 16.560 & $0,06 \mathrm{TL} /$ Geceleme \\
\hline TOPLAM & $2.005 .294,56$ & & 226,29 \\
\hline
\end{tabular}


İşletmenin toplam hizmet maliyeti 2.005.294,56 TL, birim hizmet maliyeti 226,29 TL'dir. Ancak işletmenin "toplam maliyeti, 2.304.988,38 TL"”dir. Toplam maliyetin içinde yönetim, güvenlik, satın alma, muhasebe, ana depo, pazarlama ve insan kaynakları ile ilgili giderler de mevcuttur. Bu giderler, geceleme sayısı esas alınarak maliyet nesnesine yüklenecektir.

Tablo 21: Hizmet Dışı Dağıtılmayan Giderler

\begin{tabular}{|l|r|}
\hline Giderler & Tutar (TL) \\
\hline Satıs-Pazarlama & $41.278,78$ \\
\hline Yönetim & $67.659,35$ \\
\hline Muhasebe & $47.000,47$ \\
\hline Ana depo & $28.375,33$ \\
\hline İnsan Kaynakları & $23.619,66$ \\
\hline Güvenlik & $73.390,62$ \\
\hline Satın Alma & $18.379,61$ \\
\hline TOPLAM & $\mathbf{2 9 9 . 7 0 3 , 8 2}$ \\
\hline Birim Gider & $\mathbf{2 9 9 . 7 0 3 , 8 2 / 1 6 . 5 6 0 = 1 8 , 1 0}$ \\
\hline
\end{tabular}

FTM'ye göre toplam birim maliyet $=226,29+18,10=244,39 \mathrm{TL}$

Geleneksel maliyet yöntemine göre toplam birim maliyeti=2.304.988,38/16.560 =139,19 TL'dir

Tablo 22: FTM ve Geleneksel Maliyet Yöntemine Göre Toplam Birim Maliyet

\begin{tabular}{|l|l|}
\hline Yöntem & Toplam Birim Maliyet (TL) \\
\hline FTM & 244,39 \\
\hline Geleneksel Maliyet & 139,19 \\
\hline
\end{tabular}

FTM yöntemine göre birim maliyet geleneksel maliyet yöntemine göre hesaplanan birim maliyetten daha yükssek çıkmıştır. Çünkü FTM yönteminde her faaliyetin maliyeti ayrı olarak hesaplanmış ve farklı maliyet sürücüleri kullanılmıştır. Bu durumda gerçek maliyet daha yüksektir.

İşletme, \%70 doluluk oranına göre maliyet hesaplamasına rağmen çalıştırdığ oranına göredir. Burada işletmenin amacı karşılaşılabilecek herhangi bir sapmada, hizmetin zamanında ve kaliteli yapılabilmesi için herhangi bir risk almak istememesinden kaynaklanmaktadır. Örneğin, kat hizmetleri maliyeti incelendiğinde, boşa geçen zamanın ortaya çıkmasının nedeni, doluluk oranını \% 70 , ancak çalışan personel sayısını ise 350 odaya göre esas almasındandır.

Önbüro faaliyetlerinde işlem sayısının geceleme sayısı ile doğru orantılı olmaması, bu faaliyetlerin maliyetinin hesaplanmasında, yine geleneksel maliyete göre farklılık göstermektedir. Örneğin müşterilerin odaya kayıt işlemleri her bir müşteri için bir kez yapıldığı halde, geleneksel maliyetlemede faaliyetler dikkate alınmadan önbüroda gerçekleşen maliyet toplamı tek bir maliyet sürücüsüne yüklenerek birim maliyet hesaplanmaktadır. Dolayısıyla önbüroda gerçekleşen faaliyetlerin hizmet maliyetine ne kadar etkisi olduğu hesaplanamamaktadır. İşletme FTM yöntemi uygulayarak faaliyetlerin maliyetini hesaplamakta böylece, hangi faaliyetin işletmeye olumlu/olumsuz etkisini olduğunu, faaliyetlerin ve çalışanların performansını doğru bir şekilde belirleyebilmektedir. Nitekim, önbüro faaliyetleri incelendiğinde de müşteri şikayetlerinin bölüm maliyetleri içinde önemli olduğu göze çarpmaktadır. Bunun sonucunda işletme bu maliyetleri azaltmak ve kaliteli hizmet vermek adına çalışma yapma ihtiyacı duyacaktır. Diğer yandan işletme verilen hizmet faaliyetlerinin performansını artırmak için, faaliyetlerin maliyetini inceleyerek çalışanlarını eğitebilir, yeni eleman alabilir veya faaliyetin gerçekleşmesinde olumsuz katkısı var ise eleman çıarabilir.

Sonuç olarak işletme, ulaşmak istediği hedef maliyete, faaliyetlerini inceleyerek, tam zamanında üretim ve kalite çalışmaları yaparak ulaşması mümkündür ve bu şekilde maliyetlerini azaltabileceği gibi müşteri memnuniyetini de sağlayabilmektedir.

\section{SONUÇ}

İşletmelerin hızla değişen müşteri ihtiyaçlarına cevap verebilmesi, küresel rekabet ortamında varlıklarını devam ettirebilmesi ve kar elde edebilmesi için, müşteri ve pazar üzerinde yoğunlaşmalarını gerekli hale getirmiştir. Özellikle ürün yaşam döneminin kısalması, düşük maliyetli ve yüksek kaliteli ürünleri pazara hızlı şekilde ulaştırmanın önemini artırmıştır. Ürün yaşam döneminin kısalması, kalitenin artırılarak hata ve israfların önlenmesi, değer yaratmayan faaliyetlerin ortadan kaldırılması veya azaltılması, müşteri ve pazar 
odaklı olma, işletmeleri maliyet ve yönetim muhasebesi alanında ortaya çıkan yeni yöntemlerden yararlanmalarını zorunlu hale getirmiş̧ir. Sözkonusu yöntemler, işletmelerin doğru ürün veya hizmet maliyetleri hesaplamasını, işletme için doğru kararlar alabilmesini, işletme performansını değerlendirmesini ve etkin kaynak kullanımını amaçlamaktadır.

FTM yöntemini uygulamak için, bir sistem kurulması gerekliliği kaçınılmazdır. Çünkü, FTM yönteminde kullanılan ölçütler ilişkilendirilen bölümlerde faaliyeti gerçekleştiren ve faaliyetleri kontrol eden personelin işlemleri belirlenen sürelerde yapma gerekliliği sözkonusudur. Bu da işletmeye zamanında ve kaliteli bir hizmeti gerçekleştirme olanağı yaratmaktadır. Dolayısı ile FTM, hedef maliyetlere ulaşırken tam zamanında hizmetin sunulması ve buna bağlı olarak da kaliteyi artıran bir işletim sistemi olarak görülmektedir.

FTM yöntemi her sektörde uygulanabilmektedir. Yöntemin uygulanabilir olması için, faaliyetlerin belirlenmesi ve ölçülendirilmesi gerekmektedir. Dolayısıyla konaklama işletmelerinde de faaliyetlerin düzgün şekilde belirlenmesi ve ölçülmesi sonucunda yöntem rahatlıkla uygulanabilmektedir.

FTM, gerçekleşen faaliyet için katlanılan maliyeti direkt olarak ortaya koymaktadır. Aynı zamanda da hedeflenen maliyete yaklaşılmasında maliyetlerin nerede ve hangi faaliyette kaliteyi etkilemeden azaltılması gerektiği konusunda, yöneticilere en doğru kararı aldıracak bilgileri sağlamaktadır.

Konaklama işletmelerinde gerçekleştirilen birtakım faaliyetlerde, örneğin müşteri şikayetlerinin çözümlenmesi için harcanan zamanın ölçülebilirliği tam olarak mümkün olmamaktadır. Bu da, şikayetlerle ilgili verilen hizmetin maliyetini belirlemede sapmaların olasılığını yükseltir. Ancak, önemli olan verilen hizmetin kalitesi ve müşteri memnuniyetidir.

FTM yönteminin iyi bir şekilde uygulanabilmesi için faaliyetlerin açık ve net bir şekilde tanımlanması gerekmektedir ve hepsinin standart zamanlarının ortaya konması ve kontrol edilmesi ile kalitenin artırılması sağlanır.

Konaklama işletmelerinde müşterilerin beklentilerine cevap verebilecek ve işletmeye çok fazla ek maliyet getirmeyecek bu yenilikler işletmeye uzun vadede daha yüksek kar marjı sağlayacak ve hedeflenen maliyetlere bu vadelerde yakalama şansı daha da artacaktır.

Konaklama işletmelerinde talebin esnek olması, müşteri ihtiyaçlarına anında cevap verme gerekliliğinin olması, mamul üreten işletmelere göre maliyet hesaplamalarının da daha esnek olmasını gerektirmektedir. Bu da faaliyetlerin net olarak belirlenmesini zorunlu kılmaktadır.

Faaliyet tabanlı maliyet yöntemi ve diğer yaklaşımların gelişimi incelendiğinde teknolojik gelişimlerin etkili olduğu ifade edilmektedir. Ancak, konaklama işletmelerinde teknoloji, mamul üreten işletmelere göre yoğun kullanılmamasına rağmen yani emek-yoğun işletmeler olmasına rağmen söz konusu yöntemlerin gerçek maliyetlerini hesaplamak için, doğru kararlar alabilmek ve rekabet edebilmek için uygulanması gerekliliği ortaya çıkmaktadır. Konaklama işletmelerinde değişen teknoloji yerine, değişen müşteri beklentileri yani müşteri odaklı bir hizmet sistemi gerçekleştirmek bunun için de çalışan kalitesinin en üst seviyelere çıkartılması gereklidir. Yani eğitimli personel ve bunun sonucunda müşteri memnuniyetini sağlamak konaklama işletmelerinde temel ilke olmak zorundadır. 


\section{KAYNAKÇA}

Agrawal, Surendra ve diğ., (1998) "Cost management system: an operational overview", Managerial Finance, Vol. 24 No. 1, s. 60-78.

Alsoboa, S. Sliman ve diğ., (2015) “The Impact of Usage of Strategic Decision Making Techniques on Jordanian Hotels' Performance", International Journal of Applied Science and Technology, Vol. 5, No. 1, February, s. 154-165.

Ardiansyah, Garry, Billy ve diğ., (2017) "Measuring customer profitability through time-driven activity-based costing: a case study at hotel x Jogjakarta", The 17th Annual Conference Of The Asian Academic Accounting Association (2016 Foura Conference) Book Series:SHS Web of Conferences, Volume: 34, s. 1-6.

Babad, Yair M. ve Bala V. Balachandran, (1993) "Cost Driver Optimization in Activity-Based Costing”, The Accounting Review, Vol:68, Iss:3, July, s.563-575.

Basuki, Bas ve Mertzha Dwiputri Riediansyaf, (2014) "The Application of Time-Driven Activity Based Costing In the Hospitality Industry: An Exploratory Case Study", Journal of Applied Management Accounting Research,, Volume:12, Issue:1, s. 27-54.

Bekçioğlu Selim ve Çağrı Köroğlu,. (2012) "Stratejik Maliyet Yönetimi Kapsamında Sürece Dayalı Faaliyet Tabanlı Maliyetleme Yönteminin Analizı Ve Bir Otel İsletmesinde Uygulama”, Muhasebe ve Denetime Bakış, Eylül, s. 124.

Brignall, Stan (1997) "A contingent rationale for cost system design in services”,. Management Accounting Research, 8, s. 325-346.

Cagwin, Douglas ve Marinus Bouwman, (2002) "The association between activity-based costing and improvement in financial performance", Management Accounting Research, Volume 13, Issue 1,March, s 1-39.

Chenhall, H. Robert ve Kim Langfield,-Smith, (1999) "The implementation of innovative mangement accounting systems", Australian Accounting Review, Vol:9, Iss:3, November, s. 37-46.

CIMA Global (2001) - "Activity based management - An overview", Technical briefing.

Cohen, S. Ve diğ., (2005) "ABC: adopters, supporters, deniers and unawares", Managerial Auditing Journal, 20(8/9), s. 981-1000.

Cokins, Gary (1996) Activity Based Cost Management, The McGraw-Hill Companies, Inc, United States of America.

Cooper, Robin ve Robert Kaplan, (1991) "Profit priorities from activity-based costing". Harvard Business Review, MayJune, 69(3) s. 130-135.

Dalci, Ilhan ve diğ., (2010) "Customer profitability analysis with time-driven activity-based costing: a case study in a hotel", International Journal Of Contemporary Hospitality Management Volume:22, Issue:4-5, s. 609-637.

Diavastis, Ioannis ve diğ., (2016) "The interaction effect of accounting in formation systems user satisfaction and Activity-Based Costing use on hotel financial performance: Evidence from Greece", Accounting and Management Information Systems, Vol. 15, No. 4, s. 757-784.

El-Deeb, M. S. ve diğ., (2011) "Activity Based Costing (ABC) As An Approach To Optimize Purchasing Performance In Hospitality Industry", International Journal Of Social Sciences and Humanity Studies, Vol 3, No 2, s. 319-329.

Faria, A. R. ve diğ., (2018) "Analyzing customer profitability in hotels using activity based costing", Tourism\& Management Studies, 14(3), s. 65-74.

Fathi, Zadollah ve Elham Sadat Mousavi ,Dozdahiri, (2015) "A survey of activity-based costing in hotel industry", Management Science Letters 5, s. 855-860.

Gosselin, Maurice, (2007) Handbooks of management accounting research 2, s. 641-671.

Holjevac, Avelini Ivanka (2003) "A vision of tiurismandthe hotel industry in the21 stcentury", International Journal of Hospitality Management, Vol:22, Iss:2, June, s. 129-134.

Kaplan, Robert ve Robin Cooper, (1998) Cost and Effect: Using integrated systems to drive profitability and performance, Boston: Harvard Business School Press.

Karcıoğlu, R. (2000) Stratejik Maliyet Yönetimi: Maliyet ve Yönetim Muhasebesinde Yeni Yaklaşımlar, Aktif Yayınevi, Erzurum.

Kidwell, A. Linda, ve diğ., (2002) "New management techniques: An international comparison", The CPA Journal, Vol:72, Iss:2, February, s. 63.

Latshaw, A. Craig, Cortese,-Teresa M. Danile, (2002) “Activity based costing: Usage and pitfalls”, Review of Business, Vol:23, Iss:1, Winter, s.30-32.

Mashayekhi,Bve Mohammad Ara, (2017) "Activity-Based Costing in the Hospitality Industry: A Case Study in a Hotel", World Academy of Science, Engineering and Technology International Journal of Social and Tourism Sciences, Vol:11, No:9, s. 2180-2184.

Noone, Breffni ve Peter Griffin, (1997) "Yield management and costumer profitability analysis". International Journal of Contemporary Hospitality Management, 9(2), s. 75-79.

Olotu, Ismaila ve Abdul Adamu,(2009) "The Practicability of Activity - Based Costing System in Hospitality Industry" March 30, Journal of Finance and Accounting Research, Department of Accounting, Nasarawa State University, Keffi, NasarawaState-Nigeria. Vol. 1(1), s. 36-49.

Özer, Songül ve Nilgün Bilici, (2017) "Konaklama İşletmelerinde Faaliyet Tabanlı Maliyetleme Yönteminin Uygulanabilirliğinin Araştırılması: Van İl Merkezindeki Otel İşletmelerinde Bir Uygulama" AÇÜ Uluslararası Sosyal Bilimler Dergisi Y11: 2017, Cilt: 3, Say1:2, s. 1-22. 
Patiar, Annup, (2016) “Costs allocation practices: Evidence of hotels in Australia”, Journal of Hospitality and Tourism Management, vol. 26, s. 1-8.

Pavlatos, Odysseas ve Ioannis Paggios (2007) "Cost Accountiig In Greek Hotel Enterprises: An Empirical Approach Tourismos” ,An International Multidisciplinary Journal of Tourism, Volume 2, Number 2, Autumn, s. 39-59.

Pavlatos, Odysseas ve Ioannis Paggios, (2009) "Activity-Based Costing In The Hospitality Industry: Evidence From Greece”, journal Of Hospitality\&Tourism Research,Volume:33, Issue:4, s. 511-527.

Pavlatos, Odysseas, (2011) "The Impact of Strategic Management Accounting and Cost Structure on ABC Systems in Hotels," Journal of Hospitality Financial Management: Vol. 19 : Iss. 2, s. 53-76.

Plowman, Brian (2001) Activity Based Management: Improving Process and Profitability, Gower Publishing,

Raffish, Norm ve Peter B.B. Turney (1991), "Glossary of Activity - Based Managament”, Journal of Cost Management, $5(3)$, s. 53-63.

Raffish, Norm, (1991) “How Much Does That Product Really Cost?”, Management Accounting, Vol:72, Iss:9, March, s. 36-39.

Sievanen, Matti ve Katia Tornberg, (2002) "Process-based costing: The best of activity-based costing", AACE International Transactions, CSC, s. 15.

Turney B. B. Peter,(1990) "What is the Scope of Activity-Based Costing?", Journal of Cost Management, Vol:9, Iss: 4, s. $40-42$.

TUROB, Türkiye Otel İstatistikleri, http://www.turob.com/tr/istatistikler/turkiye-otel-istatistikleri-9d67c3c , Erişim Tarihi 20.11.2019.

TURSAB,Turizm Gelirleri, https://www.tursab.org.tr/istatistikler-icerik/turizm-geliri, Erişim Tarihi: 20.11.2019.

Vazakidis, Athanasios ve Ioannis Karagiannis, (2011) "Activity-based management and traditional costing in tourist enterprises (a hotel implementation model”) OperResIntJ, 11, s. 123-147.

Vij, Madhu,(2012) “A survey of factors influencing cost structures in the Indian hotel sector", World wide Hospitality and Tourism Themes, Vol. 4 No. 5, 2012, s. 449-462.

World Tourism Organization (2018), UNWTO Tourism Highlights, 2018 Edition, UNWTO, Madrid.

Yağcı, Özcan (2003), Turizm Ekonomisi, Detay Yayıncılık, Ankara, Eylül

Zounta, Stella,;Bekiaris, Michail G., (2009), Cost-based management and decision making in Greek luxury hotels, https://mpra.ub.uni-muenchen.de/25459/1/MPRA_paper_25459.pdf, Erişim tarihi: 25.11.2019. 